Öz

Mimaride günıșı̆̆ı etkinliği mekânsal kaliteyi arttıran ve insanın doğa ile bütünleșmesini sağlayan önemli bir mekânsal tasarım girdisidir. Sürdürülebilirlik kavramı ile birlikte mekânsal konfor sartlarının daha fazla iyilestirilmesi tasarımcilardan daha fazla talep edilmeye başlanmıștır. Enerji etkinliğinin de tasarımda daha fazla konușuluyor olması, bu konuların tasarımcılar için tasarım evresinin daha erken evrelerinde düșünülme ihtiyacını doğurmuștur.

Çalıșma tasarımcılar için günıșığı bazlı bir destek modelini olușturmayı amaçlamaktadır. Model kapsamında günıșığına bağlı tasarın değișkenleri ile günıșı̆g tasarım kriterleri ilișkilendirilmekte olası sorunlara çözüm önerileri için temel rehber oluşturulmaktadır.

Bu nedenle çalışmada günıșığı faktörleri tasarımcı için rol gösterici ve sistematik biçimde ele alınarak detaylıca açıklanmaktadır. Böylece mimari tasarımda mimarların bu faktörleri daha erken tasarım evresinde kullanmaları ve içselleștirmeleri hedeflenmektedir.

Olușturulan model tasarımcının farklı önem derecelerinde bakabildiğini kabul ederek destek sistemini olușturmaktadır ve adım adım tasarımcının yanında olarak günıșığ1 konusunda tecrübeli tasarımcıların davranıș ve çözüm modelini ortaya koymaktadır. Model kapsamında farklı ișlevlerin günışığ 1 gereklilikleri de değerlendirilmekte ve sonuçta amaca yönelik aktif günıșığı tasarımı çözümü için tasarımcıya yardımcı olacak bir sistem olușturulmaktadır.

Çalıșmanın sınanması bölümünde ise bir okul yapısı seçilerek modelin çalıșması sınanmakta olası sorunların çözümleri model tarafından olușturulmaktadır.

\section{Abstract}

Daylight activity in architecture is an important design input that increases the spatial quality and enables the integration of human with nature. With the concept of sustainability, further improvement of spatia comfort conditions has started to be demanded increasingly from designers.

The fact that energy efficiency is also discussed more in design has led to the need for designers to consider these issues earlier in the design phase.

The study aims to create a daylight based support model for designers. Within the scope of the model, daylight design variables and daylight design criteria are correlated and basic guidance is provided for solutions to possible problems.

For this reason, daylight factors are explained in detail in a systematic way. Thus, it is aimed for architects to use these factors in the early design phase and internalize them in architectural design.

The model created constitutes the support system by accepting that the designer can look at different degrees of importance and support by the designer at every stage of the design.

\title{
Mimari Planlamada, Günışı̆̆ Etkinliğinin Arttırılması için Kurgusal Tasarım Destek Modeli
}

\author{
(D) Ümit Arpacioğlu \\ Mimar Sinan Güzel Sanatlar Üniversitesi, Mimarlık Bölümü \\ (D) Cemal İran Çalışkan \\ Fatih Sultan Mehmet Vakıf Üniversitesi \\ (D) Bahar Şahin \\ Istanbul Büyükşsehir Belediyesi Kültür Varlıkları Projeler Müdürlüğü \\ (D) Nazlı Ödevci \\ Kültür Üniversitesi, Mimarlık Bölümü \\ Başvuru tarihi/Received: 22.08.2019, Kabul tarihi/Final Acceptance: 04.02.2020
}

\section{Giriş}

Günışığı, tasarımda yeni bir kavram değildir. Gün 1şığının bir tasarım ilkesi olarak mimaride kullanımı, antik Roma dönemine kadar uzanmaktadır (Erel, 2004). Dönemin yapılarında, duvar açıklıklarından ışığın iç hacme alınması ilkesinin esas alındığı, bina konumlandırmalarının gün 1şığı değerlendirmesine göre belirlendiği bilinmektedir. Mekânlar elektrik ile aydınlatılmadan önce, mekân ile günıșı̆ğı ilișkisi mimarlar için büyük bir önem teşkil etmiștir. Günış1ğının, 1970'lerde yaşanan petrol ve enerji sıkıntısıyla yeniden önemi anlaşı $1 \mathrm{~m} ı s$, bu konuda bilimsel çalıșmalar yapılmış, enerji sorununun devam etmesi sebebiyle de halen üzerinde çalıșılan önemli bir konu haline gelmiştir.

Günışığı mekânsal kaliteyi arttıran ve insanın doğa ile bütünleşmesini sağlayan önemli bir mekânsal tasarım girdisidir. Son yıllarda sıkça konuşulan sürdürülebilirlik kavramı ile birlikte mekânsal konfor șartlarının daha fazla iyileștirilmesi tasarımcılardan daha çok talep edilmeye başlanmıştır. Enerji etkinliğinin de tasarımda daha fazla konuşuluyor olması, tasarımcıları bu konuları tasarım evresinin daha erken safhalarında düșünmeye yönlendirmiştir. Günışığının etkin kullanımının yararları iki ana grupta toplanabilir (IESNA, 2005; ASHRAE, 2001).
Enerji kazanımı ve 1sısal yükte azalma: Ticari yapıların enerji tüketiminin yaklaşı \%30'u aydınlatma enerjisi olarak kullanılmaktadır. Bu nedenle günıșığı ile aydınlatmanın oranı arttıkça, elektrik ile aydınlatma maliyetleri ve enerji giderleri düșmektedir (S. Hayter, Torcellini, 1999).

İnsan konforu, üretkenlik ve sağlık: Günışığının insan performansını yükselttiği kanıtlanmış bir gerçektir. Örneğin okullarda doğal aydınlatmanın etkinliği arttıkça deneysel sonuçların da iyileștiği görülmektedir. Ticari mekânlarda günıșığı, satışları arttırmakta, konutlarda günıșığına sürekli maruz kalan mekânlarda insanlar daha rahat uyumakta, hastanelerde pencereye yakın olan hastalarda uzak olanlara göre iyileșme oranı artmaktadır (Garris, 2004).

Günışığı, mimari tasarım içerisinde çok farklı boyutlarda karşımıza çıkmaktadır. Diğer fiziksel çevre konuları ile direkt ilișkili bir konu olması sebebiyle üzerinde oldukça fazla çalıșlan disiplinler arası bir konudur. Bunu Le Corbusier'in doğal sşık ve mimarlık ilişkisini vurguladığ 1 Resim 1'deki çizimlerinde ve şu sözünde görebiliriz; "Mimarlık ıșıkta bir araya getirilmiș kütlelerin ustaca, doğru ve muhteșem oyunudur".

Günıșı̆ törler mimari tasarım için önemli verileri 
oluștururlar. Tasarımda bu derece önemli payı olan ve mekânda yaşam kalitesini arttıran fiziksel çevre faktörleri, tasarım evresinde öncelikle düşünülen, ancak bir o kadar da yönetilmesi zor bir konudur. Günıșığının tasarımda etkin kullanılması elbette ki diğer fiziksel çevre değerleri ile birlikte düşünüldüğünde mümkün olmaktadır. Fakat günümüzde tasarlanan mekânlarda, günışı ̆̆ 1 faktörleri tasarım girdisi olarak yeterince tasarım sürecine dâhil olamamaktadır. Bu da toplam kalitenin düşmesine yol açarak, ciddi maddi kayıplara, iş gücü ve motivasyon kayıplarına neden olmakta ve verimliliği azaltmaktadır. Tecrübeli mimarlar tasarım süreçlerinde deneyimlerini kullanarak mekân kalitesini yükseltmeye ve sonuç ürün için gereklilikleri sağlamaya çalışmaktadırlar. Bu nedenle mimarların, özelikle erken tasarım evresinde, tasarımın fiziksel çevre değerleri açısından kalitesinin sağlanması için oldukça fazla bilgi birikimine ihtiyaçları vardır.

Tasarım ve yapım sürecinde fiziksel çevre değerleri, günümüzde yapım aşamasına yakın değerlendirilmektedir. Ne yazık ki bu aşamada tasarımcılar tarafindan yalnızca gerekliliklerin yerine getirilmesi ile süreç sonuçlanmaktadır. Problemin çözümü, fiziksel çevre değerlerinin tasarım sürecine erken dönemde katılarak, mimarlar için çözüm alternatifleri oluşturulmasında aranmalıdır.

Modernizm manifestosu mimaride, yaygınlaşan cam -çelik, cam-betonarme kullanımı ile ışık cephe tasarımın temel yaklaşımlarından biri olmuş, beraberinde günışığının bina içine alınmasını kolaylaştırmıştır (Uzun, 2019).

Dünya üzerinde teknik konuları içselleştirmiș mimarların başarılı oldukça fazla örneğini bulmak mümkündür. Le Corbusier modern mimarlık örnekleri yaratırken tasarım girdilerinden en önemlilerinden biridir günışığı ve ülkemizde Altuğ-Behruz Çinici'nin Artur Sitesi örneği 1969 yılında fiziksel ve sosyal sürüdürülebilirlik ilkelerine uygun biçimde tasarlanmış yapıların sözü edilen bağlamda öncü bir rol üstlendiği söylenebilir (Postalci \& Atay, 2019).

Tasarım süreci düşünüldüğünde, süreç devam ettikçe tasarımın değișebilirliği azalmakta iken, her değișim kararına karșı oluşan maliyetin ve alınan değişim kararını gerçekleștirme süresinin de arttığı söylenebilir. Bu nedenle hazırlanan çalışmada, erken tasarım evresinde, günışı̆̆ı değerlerini tasarım sürecine dâhil edecek bir yöntemin oluşturulmasıyla maliyet ve zamandan tasarruf sağlanacağ 1 ve bütünleşik mekân kalitesinin de arttırılacağı öngörülmüştür.

Günışı̆̆ ve fiziksel çevre değerlerinin proje sürecine erken tasarım evresinde, konsept aşamasında katılması projenin bütüncül kalitesini yükseltmekte, zamandan kazanç sağlamakta, proje maliyetlerini azaltmaktadır. Bu bütünleşik yaklaşım kalitenin yükselmesine yardımcı olurken, tasarım sürecinin ileriki aşamalarında fark1 sorunların çıkmasını da engellemektedir.

\section{Mimari Tasarımda Günışı̆̆ı Kriterleri}

Bu bölümde, tasarımı etkileyen günıșığı faktörleri açıklanacak ve ilerideki bölümlerde tasarım kriterleri olarak kullanılacaktır. Bu faktörler konuda uzman olmayan tasarımcıya destek oluşturacak bilgi birikimi ve sistematiğini oluşturmak için yapılandırılmıștır. Bazı kriterlerin konunun uzmanları tarafindan ele alış ve hesaplanma yöntemleri daha detaylı bilgi hesaplama gerektiğinden, bu kriterler olabildiğince konunun uzmanı olmayan birisinin de uygulayabileceği kapsamda ele alınmaya çalışılmıştır. Bir aydınlatma danışmanının hesaplama ve uygulama için kullandığı hesap yöntemleri ve yazılımlar bu sistemden oldukça karmaşıłk ve yoğun

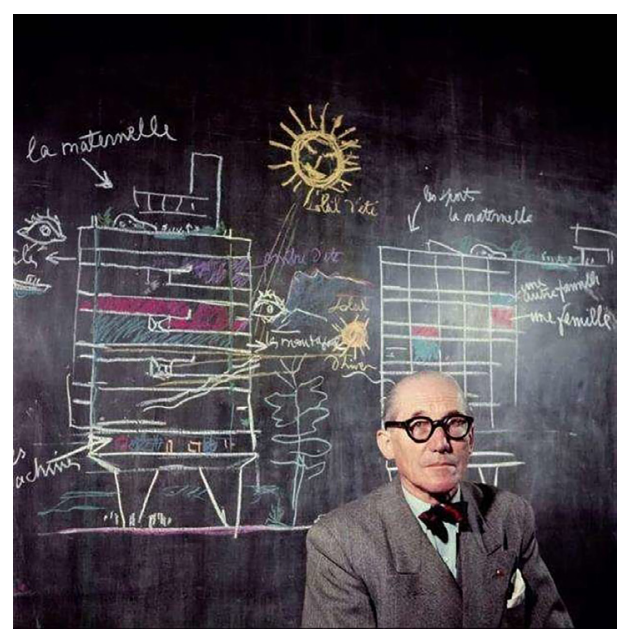

The model presents the behaviour and solution model of designers experienced in daylight.

The daylight requirements of different functions are also evaluated within the scope of the model and as a result a system is created to assist the designer for the purpose of active daylight design solution.

In the testing section of the study, a school structure is selected and the study of the model is tested and the possible problems are solved by the model.

Anahtar Kelimeler: Günıșığı, Mimari Tasarım, Fiziksel Çevre, Tasarım Destek Modeli, Sürdürülebilirlik

Keywords: Daylight, Architectural Design, Environment, Design Support Model, Sustainability

Resim: I

Le Corbusier' in güneş ve hava konulu popüler skeçleri (Antoniou \& Dimopoulos, 2018). 


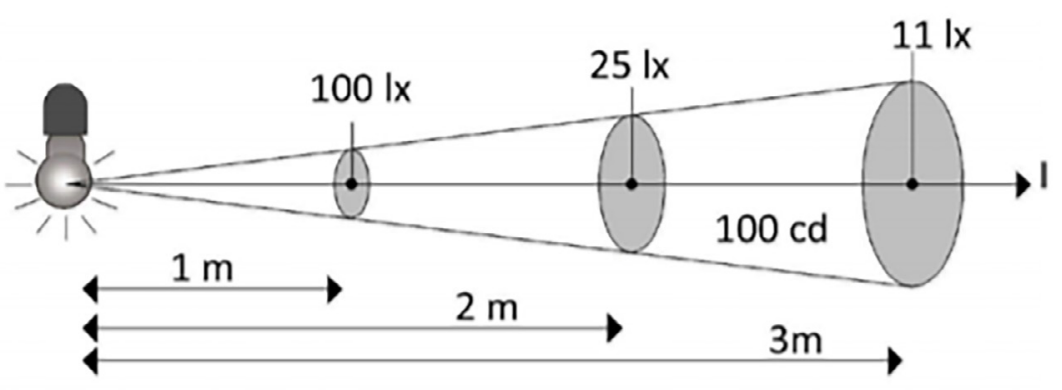

$$
E_{p}=\frac{1}{d^{2}}
$$

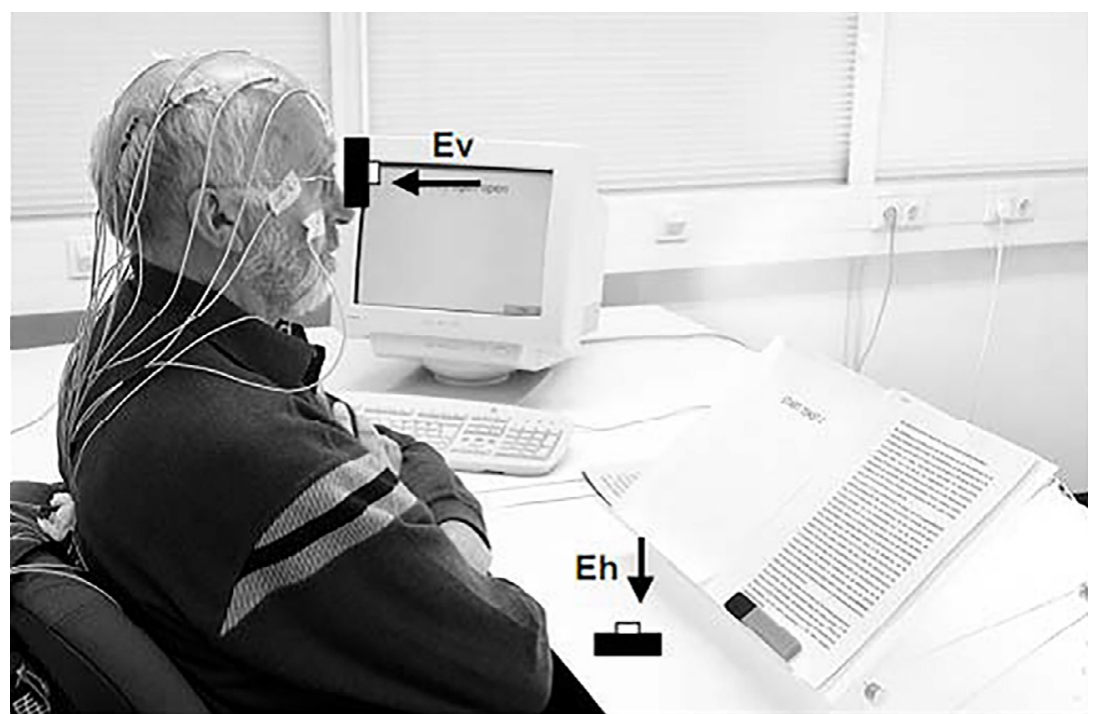

Resim: 2

Işık şiddeti, uzaklık ve aydınlık düzeyi arasındaki ilişki (şahin, 2012).

Resim: 3

Deney odasında katılımcı üzerinde ve masada görülen, Eh-yatay aydınlık düzeyi, Ev-düşey aydınlık düzeyi (Gornicka, 2008). bilgi gerektirmektedir. Çalışmanın amacı, konu için bir destek sistemi oluşturarak tasarımda farkındalık yaratmak ve bütünleşik kalitenin artmasını sağlamaktır.

\subsection{Günışı̆̆ı Aydınlık Düzeyi Faktörü}

Bir yüzeyde, birim alana düșen 1șık akısının, yüzeyin alanına bölümü “Aydınlık Düzeyi (E; $\mathrm{lm} / \mathrm{m}^{2}$ ) "olarak tanımlanır (Kayakuş, 2018).

Simgesi 'E', birimi lx' tür. Aşağıdaki formülle hesaplanır (Şahin, 2012).

$\mathbf{E}$ (Aydınlık Düzeyi) $=\Phi($ (Işık Akısı) / A (Alan)

Belirli bir yüzeye düşen 1şık şiddeti değişmediğinde, o yüzey alanında bulunan aydınlık düzeyi de değişmemektedir. Ancak, 1şı̆̆ın doğrusal yapısı, yapı içindeki dağılımı, tayfsal yapısı değişebilmektedir. Bununla birlikte 1şık şiddeti aynı kaldığı halde mesafeye bağlı olarak aydınlık düzeyi değeri azalmaktadır (Resim 2) (Şahin, 2012). Aydınlık düzeyi değeri denildiğinde, genel- likle yatay çalışma düzlemindeki aydınlık düzeyi değerleri akla gelmektedir. Ancak mekânın işlevine göre bu değişiklik göstermektedir. Yatay aydınlık düzeyi, çoğunlukla masa, çalışma yüzeyi ya da döşemede ölçülmektedir. Düşey aydınlık düzeyi ise beyaz tahta, duvarlar, tablolar, kullanıcının yüzü gibi düşey yüzeylere düşen 1şı miktarını ifade etmektedir (Resim 3) (Şahin, 2012).

Günışığının aydınlatma etkisi, yapay aydınlatmaya göre insanların daha fazla dikkatini çekmekte, memnuniyetin artmasiyla birlikte daha çok tercih edilmesine neden olmaktadır. Bina sakinlerinin tercih ettiği aydınlık düzeyleri, kişinin ışığa karşı hassasiyetine, uyku düzenine, yaşına, konfor algısına, görme kapasitesine, yapılan eylemin çeşidine göre farklılıklar gösterebilmektedir. Tasarımda günışığı aydınlık düzeyi en öncelikli değerlendirilmesi gereken faktördür. Görsel konfor için tercih edilen yüksek aydınlık düzeyleri, mekanda daha iyi görsel performans sağlayabilmekle beraber, konforsuzluğa da sebep olabilmektedir (Arpacıoğlu, 2012).

ABD’nin, aydınlatma konusunda tanınmış teknik ve eğitim otoritesi olan IES (Illuminating Engineering Society) standartlarına göre kullanıcıların yaş ortalamalarına bağlı olarak ofis binalarında 300 lx ile 500 lx arasında değișen aydınlık düzeyi değerleri öngörülmektedir. 55 yaşın üstünde kullanıcılar için 500 lx olarak belirlenen aydınlık düzeyi değeri, 55 yaşın altındaki kullanıcılar için 300 lx olarak belirlenmiştir (Arpacioğlu, 2010).

Türk Standartları Enstitüsü'nün 2013 yılında yayınladığı TS EN 12464-1 nolu standardında; iş alanı ile çevreleme alanındaki aydınlatma düzeyinin ve dağılımının görsel bir işin çabuk, güvenli ve rahatça algılanıp sürdürebilmesinde büyük bir etkiye sahip olduğu ifade edilmektedir (Türk Standartlart Enstitüsü, 2013). Standardın 5.3. maddesinde, iç kısımların (alanların), işlerin ve faaliyetlerin aydınlatma özellikleri çizelgeler halinde verilmekte olup bu çizelgelerdeki verilere göre Tasarım Destek Modeli'nde belirlenen bazı işlevlere ait sürdürülen aydınlatma yoğunluğu (Ēm) değerleri Tablo 1 'de gösterilmektedir. 


\begin{tabular}{|c|c|c|c|c|c|}
\hline \multicolumn{2}{|c|}{ İÇ KISIM, İŞ VEYA FAALIYET TİPİ } & \multirow{2}{*}{$\frac{\mathbf{E} \mathbf{m}(\mathbf{I x})}{300}$} & \multicolumn{2}{|c|}{ İÇ KISIM, İŞ VEYA FAALIYET TİPI } & \multirow{2}{*}{$\begin{array}{l}\mathbf{E} \mathbf{m}(\mathbf{l} \mathbf{x}) \\
50\end{array}$} \\
\hline \multirow{13}{*}{$\begin{array}{l}\text { EĞİTIM } \\
\text { BİNALARI }\end{array}$} & Sınıflar, özel ders odaları & & \multirow{4}{*}{$\begin{array}{l}\text { ENDÜSTRIYYEL } \\
\text { FAALIYETLER } \\
\text { VE } \\
\text { ZANAATLAR } \\
\text { (Çimento, } \\
\text { çimento ürünleri, } \\
\text { beton, tuğlalar) }\end{array}$} & Kurutma & \\
\hline & $\begin{array}{l}\text { Akşam dersleri ve yetişkin } \\
\text { eğitim için sınıflar }\end{array}$ & 500 & & $\begin{array}{l}\text { Malzemelerin hazırlanması; fırınlama } \\
\text { ve karıștırıcılar ile ilgili çalışma }\end{array}$ & 200 \\
\hline & Konferans salonu & 500 & & Genel makine işi & 300 \\
\hline & Sanat okullarındaki sanat odaları & 750 & & Kaba kalıplar & 300 \\
\hline & Teknik çizim odaları & 750 & \multirow{12}{*}{$\begin{array}{l}\text { ENDÜSTRIYYEL } \\
\text { FAALIYETLER } \\
\text { VE } \\
\text { ZANAATLAR } \\
\text { (Elektrik ve } \\
\text { elektronik } \\
\text { sanayi) }\end{array}$} & Kablo ve tel imalatı & 300 \\
\hline & $\begin{array}{l}\text { Uygulama odaları ve } \\
\text { laboratuvarlar }\end{array}$ & 500 & & \multirow{5}{*}{$\begin{array}{l}\text { Sarg1: } \\
\text {-büyük bobinler } \\
\text {-orta boy bobinler } \\
\text {-küçük bobinler }\end{array}$} & \multirow{5}{*}{$\begin{array}{l}300 \\
500 \\
750\end{array}$} \\
\hline & El iși odaları & 500 & & & \\
\hline & Eğitim odaları & 500 & & & \\
\hline & Müzik prova odaları & 300 & & & \\
\hline & $\begin{array}{l}\text { Bilgisayar uygulama odaları } \\
\text { (menülerle çalıştırılan) }\end{array}$ & 300 & & & \\
\hline & Dil laboratuvarı & 300 & & Bobinin emprenye edilmesi & 300 \\
\hline & Hazırlık odaları ve atölyeleri & 500 & & Galvanizleme & 300 \\
\hline & $\begin{array}{l}\text { Spor odaları, jimnastik salonları, } \\
\text { yüzme havuzları (genel } \\
\text { kullanım) }\end{array}$ & 300 & & $\begin{array}{l}\text { Montaj işi: } \\
\text {-Büyük transformatörler gibi kaba işler } \\
\text {-Anahtarlama kabloları gibi orta işler } \\
\text {-Telefonlar gibi ince işler } \\
\text {-Ölçü aletleri gibi hassas işler }\end{array}$ & $\begin{array}{l}300 \\
500 \\
750 \\
1000\end{array}$ \\
\hline \multirow[t]{4}{*}{ OFİSLER } & Dosyalama, kopyalama, vb. & 300 & & & \\
\hline & $\begin{array}{l}\text { Yazma, elektronik yazma, } \\
\text { okuma, veri işleme }\end{array}$ & 500 & & & \\
\hline & Teknik çizim & 750 & & $\begin{array}{l}\text { Elektronik iş yerleri,deney } \\
\text { yapma,ayarlama }\end{array}$ & 1500 \\
\hline & $\mathrm{CAD}$ iş istasyonları & 500 & \multirow{5}{*}{$\begin{array}{l}\text { ENDÜSTRIYEL } \\
\text { FAALIYETLER } \\
\text { VE } \\
\text { ZANAATLAR } \\
\text { (Gida maddeleri } \\
\text { ve lüks gida } \\
\text { sanayi) }\end{array}$} & $\begin{array}{l}\text { Aşağıda verilenler için çalışma yerleri } \\
\text { ve bölgeleri: } \\
\text {-bira fabrikaları, maltlama zemini, } \\
\text {-yıkama, fiçı doldurma, temizleme, } \\
\text { eleme, soyma için, } \\
\text {-reçel ve çikolata fabrikalarında } \\
\text { pişirme, } \\
\text {-şeker fabrikalarındaki çalışma yerleri } \\
\text { ve bölgeleri, } \\
\text {-çiğ tütünün kurutulması ve } \\
\text { mayalanması için, mayalama kabini }\end{array}$ & 200 \\
\hline \multirow[t]{2}{*}{ MÜZELER } & Sergiler, 1şı̆̆a duyarlı olmayan & $\begin{array}{l}\text { Aydınlatma } \\
\text { gösterge özellikleri } \\
\text { ile belirlenir. }\end{array}$ & & $\begin{array}{l}\text { Ürünlerin sınıflandırılması ve } \\
\text { yıkanması, öğ̈̈tme, karıştırma, } \\
\text { paketleme }\end{array}$ & 300 \\
\hline & Işığa duyarlı sergiler & $\begin{array}{l}\text { 1.Aydınlatma } \\
\text { gösterge özellikleri } \\
\text { ile belirlenir. } \\
\text { 2.Zarar veren } \\
\text { radyasyona karşı } \\
\text { koruma çok } \\
\text { önemlidir. }\end{array}$ & & $\begin{array}{l}\text { Mezbahalar, kasaplar, mandıralar, } \\
\text { mandıralar ve değirmenler, çalışma } \\
\text { alanları ve kritik bölgeler, şeker } \\
\text { rafinerilerindeki filtreleme zemini }\end{array}$ & 500 \\
\hline \multirow{2}{*}{$\begin{array}{l}\text { TIYATROLAR, } \\
\text { KONSER } \\
\text { SALONLARI, } \\
\text { SINEMALAR }\end{array}$} & $\begin{array}{l}\text { Oturma alan1 - muhafaza etme, } \\
\text { temizleme }\end{array}$ & 200 & & $\begin{array}{l}\text { Meyve ve sebzelerin kesilmesi ve } \\
\text { ayılklanması }\end{array}$ & 300 \\
\hline & Sahne alanı - donatım & 300 & & $\begin{array}{l}\text { Mezelerin imalatı, mutfak işi, puro ve } \\
\text { sigaraların imalatı }\end{array}$ & 500 \\
\hline
\end{tabular}




\begin{tabular}{|c|c|c|c|c|c|}
\hline \multicolumn{2}{|c|}{ İÇ KISIM, İŞ VEYA FAALIYYT TİPİ } & \multirow{2}{*}{$\begin{array}{l}\mathbf{E} \mathbf{\text { E }}(\mathbf{l x}) \\
\text { Aydınlatma } \\
\text { uygun atmosferi } \\
\text { oluşturmak için } \\
\text { tasarlanmalıdır. }\end{array}$} & \multicolumn{2}{|c|}{ İÇ KISIM, İŞ VEYA FAALIYET TİPİ } & $\overline{\mathbf{E}} \mathbf{m}(\mathbf{l x})$ \\
\hline \multirow[t]{3}{*}{ RESTORANLAR } & $\begin{array}{l}\text { Restoran, yemek odas1, etkinlik } \\
\text { odas1 }\end{array}$ & & \multirow{7}{*}{$\begin{array}{l}\text { ENDÜSTRIYYEL } \\
\text { FAALIYETLER } \\
\text { VE } \\
\text { ZANAATLAR } \\
\text { (G1da maddeleri } \\
\text { ve lüks gida } \\
\text { sanayi) }\end{array}$} & \multirow[t]{5}{*}{$\begin{array}{l}\text { Cam ve şişelerin muayenesi, } \\
\text { üretim kontrolü, tıraşlaması, } \\
\text { sınıflandırılması, dekorasyonu }\end{array}$} & \multirow[t]{5}{*}{500} \\
\hline & Self servis restoran & 200 & & & \\
\hline & Büfe & 300 & & & \\
\hline KÜTÜPHANELER & Okuma alanı & 500 & & & \\
\hline \multirow{3}{*}{$\begin{array}{l}\text { SAĞLIK HİZM. } \\
\text { TESİSLERİ (Genel } \\
\text { kullanım için odalar) }\end{array}$} & Bekleme odaları & 200 & & & \\
\hline & Dinlenme odaları & 200 & & Laboratuvarlar & 500 \\
\hline & Günlük odalar & 200 & & Renk muayenesi & 1000 \\
\hline
\end{tabular}

Tablo: I (devami)

TS EN 12464-I standardına göre if̧ kısımların, işlerin ve faaliyetlerin aydınlatma özellikleri(Türk Standartları Enstitüsü, 2013).
Bu değerler, yatay, dikey veya eğik olabilen iş alanı üzerindeki sürdürülen aydınlatma düzeyleridir ve normal görsel koşullar için geçerli olup aşağıdaki faktörleri göz önünde bulundurur (Türk Standartları Enstitüsü, 2013):

- Görsel rahat ve iyi hissetme duygusu gibi psikolojik-fizyolojik bakış açıları

- Görsel işler için kurallar

- Görsel ergonomi

- Uygulamayla ilgili tecrübe

- Fonksiyonel güvenliğe katkı

- Ekonomi

Görsel koşulların normal varsayımlardan farklı olduğu durumlarda, aydınlatma yoğunluğu değeri, aydınlatma yoğunlukları ölçeğindeki en az bir adım ile ayarlanabilir (Türk Standartları Enstitüsü, 2013).

\subsection{Günışı̆̆ı Faktörü (DF)}

Günışığ1 faktörünün ilk olarak, Uluslararas1 Aydinlatma Komisyonu (CIE-Commission Internationale de L'éclairage) tarafindan 1955 y1lında gerçekleștirilen Zürih kongresinde kabul gördüğü bilinmektedir. Yapılan tanımlamaya göre günıșığı faktörü, gökten gelen $1 s ̧ ı$ ğın, yatay düzlem üzerinde oluşturduğu aydınlık düzeyine oranını gösteren değer olarak ifade edilmektedir (Arpacıoğlu, 2012).

Günıșığ1, doğrudan güneșten gelen 1şık ve yaygın gök ışığından oluşmaktadır (Hülya, 2008). Zamana göre değişiklik gösteren doğal aydınlatma tasarım faktörü olarak önem taşımaktadır (Kutlu, 2019). Günışığ1- nın, iç mekânların düzenlenmesinde, insan davranışları üzerinde etkileri ispatlanmış bir faktör olarak birçok araştırmaya konu olduğu bilinmektedir (Agency \& Programme, 2000). Fizyolojik ve psikolojik yönleri ile insanı etkileyen günışığı faktörü, aynı zamanda enerji tasarrufu sağlamaya olanak sağlayan doğal bir unsur olarak, iç mekânda konfor koşullarının oluşmasında etkili olan tasarımın en önemli girdilerinden biri olarak kabul edilmektedir (Kutlu, 2019). Yapıda günışığı faktörü esas alınarak tasarlanmış bir pencere, enerji tüketimini önemli oranda azaltabilmektedir. Binada genel enerji tüketiminde, toplamın \%15 ve $\% 30$ 'luk payının aydınlatma kaynaklı olduğu bilinmektedir (Acosta, Munoz, Campano Laborda, \& Navarro, 2014). Bu bağlamda, yapıda sürdürülebilirlik kavramının, günıŞı̆̆1 faktörü ve parametreleri ile doğrudan ilişkili olduğu ifade edilebilir.

Günıșığı tasarım stratejileri, yapının bulunduğu diğer binalar ile olan pozisyon ve şartlar da dikkate alınarak belirlenen doğal 1şığın varlığına bağlıdır (Agency \& Programme, 2000). Mevsim ile ilgili iklimsel değişiklikler de günışığı stratejisinde önemli bir faktörü oluşturur.

Yapıda pencere ölçüsü, pencere formu ve oda ölçüleri, gün 1şığını etkileyen temel üç faktör olarak sayılabilir (Vaisi \& Kharvari, 2019). Bu faktörlerden birincisi olan, cephede pencere ölçüsünün belirlenmesinde ise temel üç faktörün doğrudan etkili olduğu bilinmektedir (Athanassios Tzempelikos \& Athienitis, 2007). Bunlardan birincisi, mekâna gün 
ıșığının alınmasıdır ki; yeterli ölçülerde tasarlanan pencere, gün ıșı̆ıının iç mekâna alınmasında doğrudan etkili iken, gereğinden büyük ölçülerde tasarlanan pencerenin özellikle güneye bakan cephelerde kamaşma sorunları yaratabileceği ifade edilebilir. Tzempelikos, pencere ölçüsü belirlenmesinde etkin diğer faktörleri, aydınlatma, 1sıtma ve soğutma amaçlı olarak kullanılan enerjinin azaltılması olarak ifade etmektedir (Athanassios Tzempelikos \& Athienitis, 2007). Binalardaki enerji tasarrufu konusunda Avrupa Birliği'nin EN 15193 (Energy Performance of Buildings' Energy Requirements, 2007) standardı, aydınlatma sistemlerini binanın enerji performans değerlendirmesi için uygun bir unsur olarak görmesi, günıșığını yapı tasarımlarında daha önemli bir faktör durumuna getirmiștir (Bellia, Cesarano, Iuliano, \& Spada, 2008).

Günıșığ1 Faktörünün; “Gök”, "D1ș Yansımıș", "İç Yansımıș" olmak üzere üç bileșenden oluştuğu bilinmektedir. Gök bileșeni, sky component olarak da ifade edilen, gökten dolaysız olarak içeri giren ve gözlem noktasına ulaşan günıșığını ifade etmektedir. "Externally reflected component" olarak literatüre geçen diș yansımış bileșen, gökten gelen ıșığın diş yüzeylerdeki engeller üzerinden yansıyarak gözlem noktasına ulașması olarak tanımlanmaktadır. Bina içerisindeki gözlem noktasına, binayı çevreleyen diğer yapılar, zemin kaplamaları, saydam yüzeylerden yansıyan ıșık bu kapsamda ele alınmaktadır. Pencereyi geçen gün ıșı̆̆ııın, iç yüzeylerde yansıyarak gözlem noktasına ulașması ise, iç yansımıs bileșen (internally reflected component) olarak ifade edilmektedir (Resim 4) (Arpacıŏ̆lu, 2010).

Günışığı konusunda yapılmıș bilimsel araştırmalara bakıldığında, bazı ülkelerin belirli mekânlar için sınır değerler belirledikleri görülmektedir. Yapıda cephenin 1 șık performansı olarak ifade edebileceğimiz günışı̆̆ı faktörü, dıș ve iç mekân arasındaki doğal ıșık oranı olarak açıklanabilir. Bu oranda $\% 2$ altı ve $\% 5$ üstü değerlerinin genel anlamda memnuniyetsizlik sınırını olușturdukları ifade edilebilir. \%2 altı değer, yetersiz günıșı̆̆ını; \%5 üstü değer,

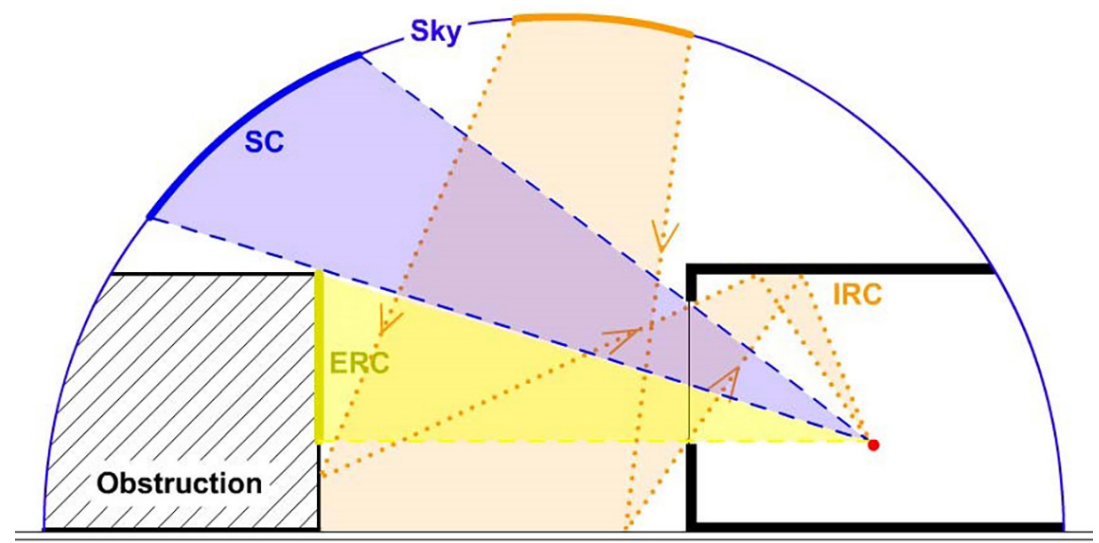

kamaşma sınırını ifade etmektedir. Mimari form ve tasarım stratejilerinin belirlenmesinde günıșığı limitlerine uyumluluk; yaResim: 4 Günışı̆̆ı Faktörü (Daylight Factor DF) bileşenleri(Arpacıoğlu, 2010). pının enerji, konfor, insanın fizyolojisi ve psikolojisi gibi birçok alana uygun mimari özellikler taşımasına yardımcı olacağı gibi, yapının estetik görünüm ve başarısına da katkı sağlayacaktır (Taşoluk, 2014).

\subsection{Günışığı Kamaşma Faktörü}

Kamaşma uygun olmayan bir parlaklık dağılımından kaynaklanan, görsel performans1, ayrıntıları ve nesneleri tanımlama yeteneğini düșüren, görme duyusunda kısmi rahatsızlığa neden olabilen özel durum olarak tanımlanmaktadır (Bellia et al., 2008). Günıșığı Kamașma Faktörü, günıșığ doğrudan bağlantılı bir faktördür. Doğrudan güneș ıșığı ve iç, dıș yüzeylerden gelen ikincil yansıma ile ilișkilidir. Özellikle kullanıcının mekânı, yer değiștirmeden kullandı $\breve{g}$, ofis, okul, fabrika gibi yapılarda önem taşımaktadır. İnsan üzerindeki etkisi kapsamında; psikolojik (discomfort glare), fizyolojik (disability glare), köreltici kamașma (blinding glare) olmak üzere üç grupta incelenebilir (Klllç, 1994). Bu üç grup, oluşma durumlarına göre kendi içlerinde, dolaysız kamaşma (direct glare) ve yansıma kamaşması (reflected glare) olarak ele alınmaktadır (Bellia et al., 2008).

Kamaşmanın oluşmasındaki etkenler, günümüzde halen tam olarak bilinmemekle birlikte (Pierson, Wienold, \& Bodart, 2017); literatürde karşılaștığımız bazı etkenleri şu şekilde suralayabiliriz (Kllıc, 1994):

- Kaynağın büyüklüğü ve 1şıklılığı

- İlgili doğrultudaki ışık yeğinliği 
- Kaynağın görme alanındaki konumu

- Ortamın genel 1şıklılığ1

- Görsel ișlevin süresi

Kamaşma oluşmasındaki etkenlerin, aydınlatma ile ilgili, şartlar ile ilgili ve konu ile ilgili olmak üzere üç ana grupta ele alındığı görülmektedir. Yapılan bu çalıșmada daha önceki araștırmalar üzerinden belirlenen faktörler; kesin, muhtemel, kesin olmayan gibi etki olasılıkları ile değerlendirilmiştir (Pierson et al., 2017). Bu değerlendirme başlıkları arasında; parlama kaynağının parlaklığı, adaptasyon seviyesi, kontrast etkisi, gözlemci tarafından görülen parlama kaynağının boyutu gibi faktörler kesin etki sınıfında; görüș açısı, günlük zaman dilimi, görev zorluğu, önceki aydınlık ortam gibi faktörler muhtemel etki sınıfında; duygusal durum, kafein alımı, yiyecek alımı, yorgunluk gibi faktörler kesin olmayan etki sınıfında değerlendirilmiștir.

Kamaşma konusunda yapılan araștırmalarda, sonuçlar arası analitik değerlendirme ve rahatsızlık derecesi, çeşitli modeller ile açıklanmakla birlikte, evrensel bir metottan bahsetmek mümkün görülmemektedir. Kamaşma öngörüsüne yönelik kullanılmakta olan modeller Günıșığı Kamașma Endeksi (DGI - Daylight Glare Index) veya Gün Işığı Parlama Olasılığı (DGP - Daylight Glare Probability) isimleri ile ifade edilmektedir (Pierson et al., 2017). Bina içinde belirlenen bir gözlem noktasındaki kamaşma durumunu ölçmek üzere, DGP ve DGI dıșında bazı günışığı kamaşma tahmin modelleri de kullanılmıştır. Diğer tahmin modelleri, BGI (British Glare Index), CGI (CIE Glare Index), UGR (CIE Unified Glare Rating) isimleri ile bilinmektedir. Bu tahmin modellerinden DGI, UGR ve DGP'nin en yoğun kullan1lan modeller olduğu ifade edilebilir (Hamedani et al., 2019).

Tablo: 2

Kamaşma etkisi matematiksel fonksiyonu ve dört temel değisken(Hamedani et al., 2019).

\begin{tabular}{|ll|}
\hline \multicolumn{1}{|c|}{$G=\left(\frac{L_{s}^{e} \cdot \omega_{s}^{f}}{L_{b}^{g} \cdot f(P)}\right)$} \\
\hline$G \quad$ Kamaşma \\
\hline$L_{S}^{e}$ & $:$ Parlama Kaynağının Parlaklığ 1 \\
\hline$\omega_{s}^{f}$ & $\begin{array}{l}\text { : Kaynak ile Gözlemci Arasında Oluşan } \\
\text { Açı }\end{array}$ \\
\hline$L_{b}^{g}$ & : Arka Planın Parlaklığ 1 \\
\hline$f(P)$ & : Pozisyon Endeksi \\
\hline
\end{tabular}

Türk Standartları Enstitüsü'nün 2013 yılında yayınladığ1, EN 12464-1 (2002) standardı üzerinden hazırlanan, TS EN 12464-1 nolu standart, rahatsız edici kamaşma yöntemi olarak CIE Birleşik Göz Kamașması Değeri (UGR) tahmin modelini temel almakla birlikte, bu konuda standart bir yöntemin olmadığına da vurgu yapar (Türk Standartları Enstitüsü, 2013) Tahmin yöntemleri konusunda yaptığımız literatür araştırmasında, bu yöntemlerin, yüksek parlama kamaşmaları tahmini noktasında yetersiz kaldıklarını ifade eden bazı değerlendirmelere de rastlanmıştır (Suk \& Schiler, 2012).

$\mathrm{Bu}$ tahmin modellerinin, temel olarak dört fotometrik değer odaklı çalıștığ1 bilinmektedir (Tablo 2). Kamaşma etkisi ile ilgili yapılan fiziksel ölçümler ve algılanan parlama arasındaki ilişkiyi, bu dört temel değişken üzerinden tanımlayan bir matematiksel fonksiyon da türetilmiștir (Hamedani et al., 2019). Pierson, Wienold ve Bodart, kamaşma tahmini üzerine yazdikları makalede (Pierson, Wienold, \& Bodart, 2018), kamașmayı etkileyen bu dört temel matematiksel değerin ilk olarak 2015 y1lı yapılan bir çalışmada (Khanie, Wienold, \& Andersen, 2015) tanımlandığını ifade eder.

\subsection{Günışı̆̆ı Aydınlanma Oranı Faktörü}

Günışı̆̆ı Etkinliği (DAR - Daylight Availability Ratio) analiz yapılan mekân için öngörülen aydınlık düzeyi seviyesinin o mekân için yeterlilik oranını vermektedir. Mekân işlevine uygun saat aralıkları diliminde, yıl içerisinde bahar aylarında, yaz aylarında ve kış aylarında analiz yapılarak günıșığı etkinliği belirlenir. DAR, aydınlatma enerjisi ve görsel konfor ile yakın ilişkili ve yılın farklı zaman dilimlerinde farklılık gösteren bir parametredir (Athanasios Tzempelikos, 2005).

DAR hesaplamaları tüm yılı kapsayan akademik çalışmalarda kullanılan ve literatürde diğer faktörlere göre görece daha az karşılaşılan fakat önemli bir değerlendirme kriteridir. Fakat tasarımcıların bu uzman hesaplamaları tüm yıl için yapmaları bir akademik çalışmayı gerektireceğinden, oluşturulan modelde DAR'ın, yılın en az dış aydınlığa sahip olduğu kabul edilen 21 Aralık günü, kapalı hava şartlarında hesaplanmasının ve mekânsal yeterliliğe ba- 
kılmasının tasarımcıya daha hızlı ve pratik bilgi üreteceği kabul edilmiștir. Bu nedenle kriterin ismi de literatürde karıșıklığa neden olmamak için "Günışı̆̆ı Aydınlanma Oranı" olarak belirlenmiștir.

Biraz daha açıklamak gerekirse, Aydınlık Düzeyi ve Günışığı Faktörü (DF) ölçümlerinde mekânın ortalama değerlerine bakılmaktadır. Bazı mekanlarda ortalama değer tutturulmasina rağmen, mekân içinde bulunan kullanıcılar için mekânın büyük çoğunluğunda bu değerlerin sağlanması tasarım kalitesi açısından büyük öneme sahiptir. İleriki bölümlerde anlatılacak Düzgünlük Faktörü'nden farklı olarak, mekânın gerekli Aydınlık Düzeyi seviyelerinin homojen dağılıp dağılmadığı, belirli yerlerde 1şık toplanmalarının ya da yetersizliklerinin olup olmadığı bu faktörle anlaşılabilmektedir. Bir mekân için gerekli Aydınlık Düzeyi'nin 300 lx olduğu bir durumda, mekân hesaplamalarında ortalama aydınlık düzeyi bu değeri sağlasa bile mekânın 300 lx'ün altında kalan yüzdesi tasarım kalitesi açısından değerlendirilmelidir.

Standart ve yönetmeliklerde olmayan bu konu daha çok akademik çalışmalarda cephenin performans kriteri olarak kullanılmıştır. Bu nedenle olması gerekli sınır değerleri mevcut değildir. Hazırlanan modelde bu konu ile ilgili alınan kararlar da diğer faktörler gibi gerektiğinde değișebilir, gelişebilir niteliktedir. Literatüre bağlı olarak dış aydınlığın bulunduğu yılın tüm zamanlarında mekânın aydınlık yeterliliğinin \%80'in üzerinde olması öngörülmüştür.

\subsection{Günışı̆̆ı Düzgä̈nlük Faktörü}

Günışığı Düzgünlük Faktörü (GDF), aydınlatılmış bir mekanın en karanlık noktasındaki aydınlık düzeyinin, mekanın ortalama aydınlık düzeyine oranıdır (YTÜ, 2019). Mekanlar arasında geçișlerde veya aynı mekan içerisinde aydınlık düzeyinde bir fark oluşması durumunda bu geçiş kontrollü șekilde yapılarak, kamaşma veya karanlık alanlar oluşması engellenmelidir (T.Arpacıoğlu, 2010). Svetlana Olbina 2005 yılında tamamladığ 1 doktora çalışmasında, Günışığı Faktörü'nün mekan içerisindeki farkının \%30'u geçmeyecek şekilde (DFmin/DFortalama $\geq 0.3)$

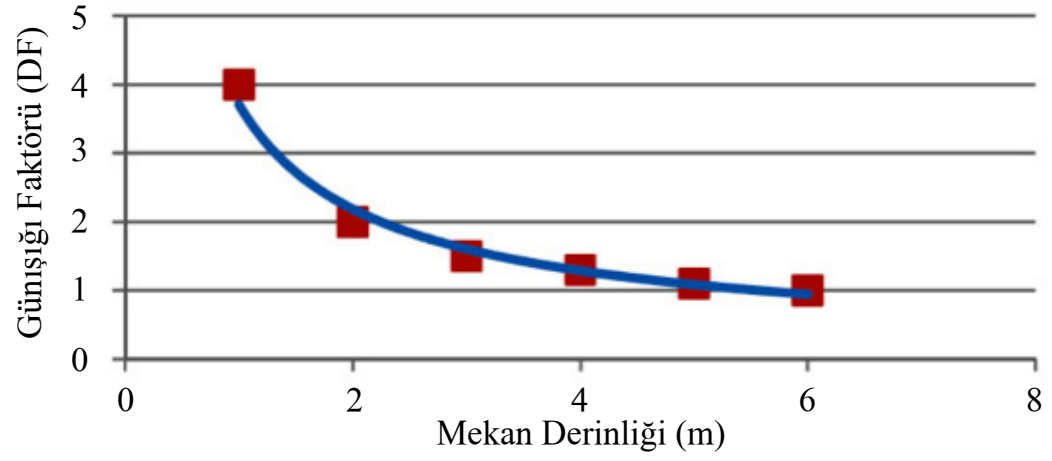

tasarım yapılması gerektiğini belirtmiştir (Olbina \& Beliveau, 2010). Bu tanıma göre; Arpacıoğlu'nun geliştirdiği, Günışığı Grafik: I Günışı̆ıı Düzgünlük Faktörü (GDF) grafik gösterimi.
Öncelikli Fiziksel Çevre Tasarım Destek Modeli'nde, cepheden mekan içindeki en derin noktaya doğru bir metre aralıklarla seçilen tasarım noktalarının aydınlanma değișimini gösteren Günıșığı Düzgünlük Faktörü grafik gösterimi aşağıda Grafik 1'de belirtilmiștir (Arpacıoğlu, 2010).

Düzgünlük faktörü, birim alana düşen 1şık şiddetinin minimum olduğu noktanın, ortalama aydınlığa oranı olarak da tanımlanmaktadır. İç mekanlarda görsel konfor koşullarını sağlamak ve kontrast farklarının oluşumunu kontrol etmek için düzgünlük faktörü gereklidir (Yilmaz, 2016).

Yapı sektörüne enerji verimliliği konusunda yön veren yeșil bina sertifikalarında da düzgünlük faktöründen "günıșığı" baş̧lı̆ı altında bahsedilmektedir. Bu sertifika sistemlerinden BREEAM (Building Research Establishment's Environmental Assessment Method) ilk olarak 1990 yılında İngiltere'de kullanılmaya başlanan, daha sonra tüm dünyada kabul görmüș olan bir yeșil bina sertifika sistemidir. Bu sertifika sisteminde amaç bir binanın çevreye etkisi ve verimlilik performansının standartlar ile ilișkilendirilerek ölçümünün yapılmasıdır. Aydınlatma da kişinin psikolojik ve fiziksel koşullarını en çok etkileyen faktörlerin başında gelmektedir. BREEAM'de günışı̆̆ bölümünde, gerekli ortalama günışı̆̆ faktörünün minimum değerlerini belirten Tablo 3 aşağıda gösterilmiş̧ir (BRE, 2011).

Günışığı düzgünlük faktörünü sağlamak için,

a) En az \%3 düzgünlük oranı veya Tablo 3 ’teki ortalama günıșığı faktörü değerinin 


\begin{tabular}{|l|l|c|c|c|}
\hline Bina tipi / arsa tipi & Krediler & $\begin{array}{c}\text { İstenilen ortalama } \\
\text { gün ıșı̆ı̆ faktörü }\end{array}$ & $\begin{array}{c}\text { Uyulması gereken } \\
\text { asgari alan }\left(\mathbf{m}^{2}\right)\end{array}$ & Diğer șartlar \\
\hline İç mekan birleşme veya iç avlu alanı & & $\% 3$ & $\% 80$ & En az 0.7 düzgünlük faktörü oranı ya da minimum \\
$\% 2.1$ gün ş̧ığı faktörü
\end{tabular}

Tablo: 3

Gerekli ortalama günışı̆̌ faktörünün minimum değerleri.
Resim: 5

Düzgünlük: Cepheden gelen ışık (soldaki oda) ve tavadan gelen ışık (sağdaki oda) (Neufert, 2002). en az \%3 katı "minimum nokta günıșığ1 faktörü” gerekmektedir. Orta avlular gibi üstü cam çatı ile kaplı boşluklar, Tablo 3 'teki ortalama gün 1şığı faktörü değerinin en az $\% 7$ katı bir minimum eşitlik oranına veya en az \%7 gün ıșıma faktörüne sahip olmalidir (BRE, 2011).

b) İç mekanların en az \%80’i masa veya masa üstü yüksekliğinden dışarı bakıld1ğında nitelikli bir gökyüzü manzarasına sahip olmalıdır (konut yapılarında yerden 0.85 m yükseklikte, ofis vb. işlevli diğer binalarda $0.7 \mathrm{~m}$ yükseklikte) (BRE, 2011).

c) Oda derinliği kriteri şu şekilde karşılanmalıdır: d / w + d / HW <2 / (1-RB) $\mathrm{d}=$ oda derinliği, $\mathrm{w}=$ oda genişliği, HW $=$ Zemin seviyesinden pencere yüksekliği, $\mathrm{RB}=$ odanın arka yarısında yüzeylerin ortalama yansıması

Günışığının cepheden veya tavandan alınması da düzgünlüğü etkileyen önemli bir faktördür. G ile ifade edilen günışığı aydınlatmasının homojenliği (Dmin / Dmax olarak nitelendirilen), cephedeki düşey bir doğramadan alınan 1şık durumunda $\mathrm{G} \geq$ Dmin/Dmax 1:6 olmalıdır. Tavandan gelen 1şı durumunda ise $\mathrm{G} \geq \mathrm{Dmin} / \mathrm{Dmax}$ 1:2 olmalıdır. Bu tanımlama iç alanlardaki günıșığının değişimini tarif eder. Düzgünlük faktörü, üstten aydınlatma durumunda daha iyidir, çünkü tepe 1şığı parlaklığı ufuktaki parlaklıktan üç kat daha fazladır (Resim 5) (Neufert, 2002). Duvarda ise, duvarın yans1tıcılığı ile düzgünlük arasındaki ilişkiye bakılırsa, daha yüksek bir duvar yansıtmasının doğrusal bir şekilde daha yüksek bir tek düzgünlükle sonuçlandığı görülmektedir (Mangkuto, Rohmah, \& Asri, 2016).

Düzgünlük faktörü, okul (derslik), ofis (çalışma alanları) ve dükkân (ticari alanlar) gibi iç mekânda homojen bir aydınlığın gerekliği olduğu işlevler için büyük önem taşır. Ticari alanlarda göze hitap eden ortamların yaratılması için Tablo 4'te verilen düzgünlük faktörü kriterleri yerine getirilmelidir (Yilmaz, 2016).

Eğitim alanlarında da kaliteli bir eğitimin söz konusu olabilmesi için ışı̆̆ın eşit şekilde mekânda dağılması önem arz eder. Sınıf ortamındaki günışı̆̆ının kullanılabilirliği, öğretmen ve öğrencilerin görsel işlerini kolaylıkla yapabilmelerini sağlayacak kadar yüksek olmalıdır. Bununla birlikte
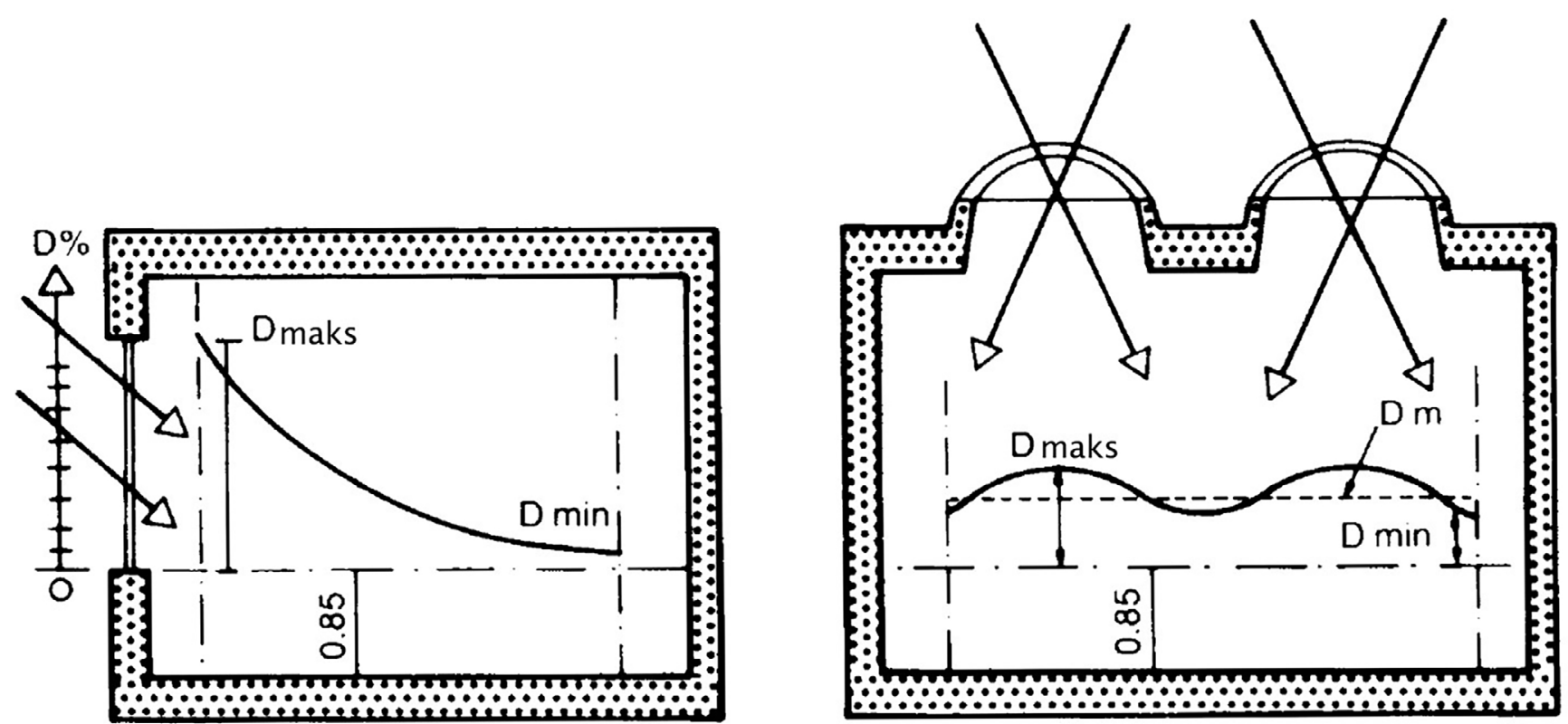
günışığı sınıf içerisinde eşit olarak dağıtılmalıdır. Günışığının iç mekandaki aşırı dağınık yayılımı öğrencilerin görsel işlerini yapmalarını zorlayabilir (Costanzo, Evola, \& Marletta, 2017).

Cephedeki güneș kırıcılar düzgünlüğün sınıf içerisine yayılmasına engel olur çünkü sınıfta 1șı tek bir cepheden gelmektedir. 6 metreden daha derin olan sinıflarda, aydınlık olan cephe tarafı ile odanın diğer ucu arasındaki kontrastı artıran aydınlık seviyelerinde bir fark vardır. "Guide for Daylighting Schools" kitabına göre sinıfin yeterince günışığı alabilmesi için cam cephe oranının sinıf tabanına oranı \%8-\%11 arasında olmalidır (A Tzempelikos \& Athienitis, 2015).

\subsection{Yıllık Günışı̆̆ı Etkinliği Faktörü}

Geliştirilen Modelde Yıllık Günıșığı Etkinliği Oranı, bir mekân için yıllık yapay aydınlatma gerektirmeden günıșığ 1 ile gerekli aydınlık düzeyini sağlama oranı olarak kabul edilmiştir. Yapay aydınlatmanın dolaylı olarak kullanılmama oranını vermektedir. Tasarlanan mekân için ortalama günıșığı faktörü bilgisi ile belirlenen yapay aydınlatma kapalılık oranı, o mekân için gerekli aydınlık düzeyinin değerine bağlı olarak bulunabilmektedir. Yapay aydınlatmanın kontrol biçimi de günışığı aydınlanma oranını belirlemede etkili olmaktadır (BRE, 1985).

Günıșığı aydınlanma oranının, geliştirilen modelde tasarımcı eğilimine göre ve fonksiyona göre değişiklik göstermekte olduğu, iklimsel bölgeye göre ise değișiklik göstermediği kabul edilmiștir. İșleve göre değișen günışığı aydınlanma oranı seviyeleri, mekânın kullanımları arasındaki farklılıklara göre değerlendirilerek kabul edilmiștir.

Günıșığı aydınlanma oranı ile ilgili yapılan çalışmalar, olması gereken sınır değerleri belirleyebilmek için oldukça sınırlıdır. Bu nedenle literatüre bağlı kabule dayalı olarak minimum sınır değerleri kabul edilmiştir. Literatüre bağlı olarak, standartlarda gerekli görülen aydınlık düzeyi şartlarını mekânın \%80'inin sağlaması gerektiği öngörülmüss ve 21 Aralık günü, saat 12.00 için kapalı hava şartları seçilerek hesaplamalar yapılmıștır.

\begin{tabular}{|l|c|}
\hline EN 12464 Standart & $\mathrm{U}_{\mathrm{O}}$ \\
\hline Satıș Alanı & 0.4 \\
\hline Kasa Alanı & 0.6 \\
\hline Paketleme Alanı & 0.6 \\
\hline SLL Aydınlatma El Kitabı & $\mathrm{U}_{\mathrm{O}}$ \\
\hline $\begin{array}{l}\text { Genel profil (Dükkan tipinden } \\
\text { bağımsız olarak) }\end{array}$ & en az 0.7 \\
\hline $\begin{array}{l}\text { IESNA Aydınlatma El Kitabı (dükkan } \\
\text { tiplerine göre) }\end{array}$ & $\mathrm{U}_{\mathrm{O}}$ \\
\hline Büyük mağaza (genel satıș) & $0.33-0.66$ \\
\hline
\end{tabular}

\section{Aktif Günışı̆̆ı Tasarımı Destek Modeli}

Tasarım sürecinde mimarlar analitik yapıda rasyonel kararlar verdikleri gibi içgüdüsel, keyfi kararlar da verebilmektedirler. Fakat fiziksel çevre değerleri ve teknik konular ile ilgili karar mekanizması çoğunlukla analitik yapıda gerçekleşmektedir. Bu süreçte tasarımcının tecrübesi ve bilgi birikimi, tasarımın o andaki sorunlarını belirlemede öncelikli rol oynamaktadır. Mekân tasarımında günışığı değerlerinin etkinliğinin arttırılması için oluşturulacak modelde, günıșığı ekseninde detaylanan ve mekânın aktif günışığı tasarımını sağlayacak bir kapsam belirlenmiştir.

\subsection{Amaç ve Hipotez}

Bir "Tasarım Destek Modeli” olan ve mekânsal kalitenin arttırılmasını amaçlayan bu çalışma, günışığı ve günışığına bağlı tasarım kriterleri ile bu kriterlere bağlı tasarım değișkenlerini ele almaktadır. Böylece günışığı konusunda tecrübesiz bir mimarın bilgi birikimi desteklenmiş ve tasarımın günışığı sorunlarının çözümü ile ilgili destek sistemi kurulmuş olacaktır. Hazırlanan çalışmada, erken tasarım evresinde, günıșığı değerlerini tasarım sürecine dâhil edecek bir yöntemin olușturulmasının maliyet ve zamandan tasarruf sağladığı gibi bütünleşik mekân kalitesini de arttıracağı öngörülmüștür.

Geliştirilen "Kurgu Modelin" dayandığ 1 hipotezler şu şekilde sıralanabilir.

- Mimarın "Aktif Günıșığı Tasarımı” konusunda gösterdiği karar verme davranıșı modellenebilir. 
- Tasarımı etkileyen günıșı̆ğ verileri birbirleriyle kesin olarak ilişkilidir. Dolayısıyla fiziksel çevre sorunlarının tek başına değil, bütünleşik ele alınarak çözümlenmesi toplam kaliteyi arttırarak tasarım sürecine destek olur.

- Tasarımda günışığı değerlerinin tasarım sürecine dâhil olma aşamasının öne çekilmesi, erken tasarım evresinde tasarımcının fark etmediğ $i$ ya da önemsemediği birçok konfor sorununu çözerek, tasarımın gelişmesine, esneklik kazanmasına, zaman tasarrufuna ve maliyetin düşmesine olanak tanır.

- İșleve, tasarımcı eğilimine, yönelmeye ve iklimsel verilere göre değișen çözümleme aşaması, tasarımın sorunlarının daha net ortaya çıkmasını ve bu sorunlara karşı çözümlerin erken tasarım aşamasında daha kolay bulunmasını sağlamaktadır.

- Tasarımcı için rehber niteliği taşıyan tasarım değișkenleri ile Günıșığ 1 Kriterleri ilişki değerlendirmesi, tasarımın günıșığı sorunlarına bütünleșik ve daha verimli çözüm bulunmasını sağlar.

\subsection{Modelin Yöntemi}

Günışığı konusunda, özellikle erken tasarım aşamasında kullanılması amaçlanan modelin yaklaşımı öncelikle bilgi birikimi oluşturmak ve tecrübeli tasarımcıların teknik yaklaşımlarını model alarak, bu konuda daha az bilgiye ve tecrübeye sahip tasarımcıya destek sistemi oluşturmaktır. Model ile ilgili tecrübesi olan uzmanların günışığı tasarımı konusundaki yaklaşımlarını sistematik biçimde ortaya koyarak bir yaklaşım oluşturmayı amaçlar. Model sadece günıșığının temel konularını erken tasarım aşaması için ele alır.

Modelin ele aldığı problem; günümüzde tasarımciların tasarım girdilerinin artmakta oluşu ve bu girdiler sonucunda çoğunlukla yönetmeliklerin öngördüğü tasarım problemlerinin çözümlerine ağırlık verilmesidir. Bu durum günıșığ gibi görsel konforun yanında isısal konfor ve enerji performansını etkileyen fakat yönetme- liklerde sınırlı derecede ele alınan teknik konularda tasarımın görece zayıflamasına neden olmaktadir.

Modelin hipotezi, "Günışığ Etkinliği Konusunda Tecrübeli Bir Mimarın Tasarım Yaklaşımları Modellenebilir" şeklinde yazılabilir. Bu konuda uzmanlığı olan akademisyenler ve piyasa tecrübesi olan kişilerden uzman görüşü yöntemini kullanarak bir platform çalışması yapılmıştır. Çalışmaya 3 akademisyen, 3 doktora öğrencisi, 2 piyasada günışığı konusunda çalışan uzman çağrılarak görüşleri alınmış, model içinde kullanılan akış ve çözüm ağırlıkları revize edilmiştir.

Çalışma yöntemi olarak, uzman tasarımcının tasarıma yaklaşım sistematiği ve öncelikleri ilk aşamada yapılandırılmıştır. Daha sonra mekânın ișlevsel farklılıklarının günışığı kriterlerine göre öncelikleri belirlenmiş ve tasarım eğilimlerinin de günışığı çözümlerinde farklılık gösterebileceği kabulüne dayanarak model akıșı yapılandırılmıştır.

Model içinde kullanılan kriterlerin hesaplama ve sonuç üretme sistemi, özellikle bu konudan anlamayan tasarımciların uygulayabileceği seviyede tutulmaya çalışılmıştır. Konunun uzmanlarının kriterler için gerçekte uygulayacakları hesap ve analiz yöntemlerinin daha kapsamlı ve doğru sonuç üreteceği unutulmamalıdır.

Model, erken tasarım evresinde tasarımc1ya Günışığı Tasarımı konularında destek olmak için tasarım sürecine dâhil olmakta ve model sonuçları tasarımcı tarafindan değerlendirilmektedir. Tasarım değișkenleri ile günışı̆̆ kriterleri arasındaki ilişki tasarımcıya tanımlanarak, tasarıma özgü bütünleşik çözümlerin oluşturulması sağlanmaya çalışılmaktadır. Model bir döngüden oluşmaktadır. Model için gerekli bilgi toplandıktan sonra, tasarım önerilerinin tasarımcı tarafından yeniden değiștirilmesi ile modelin çözümleme aşamasına geri dönülmektedir. Tüm sorunlar çözülüp model akışı tamamlandığında ise tasarımın görece günışığı aktif bir tasarım olması sağlanmış olur. Model bu yönü ile "Kurgu Model" olmasına rağmen tasarımcı ile etkileșen bir değișkenlik de sağlamaktadır. 


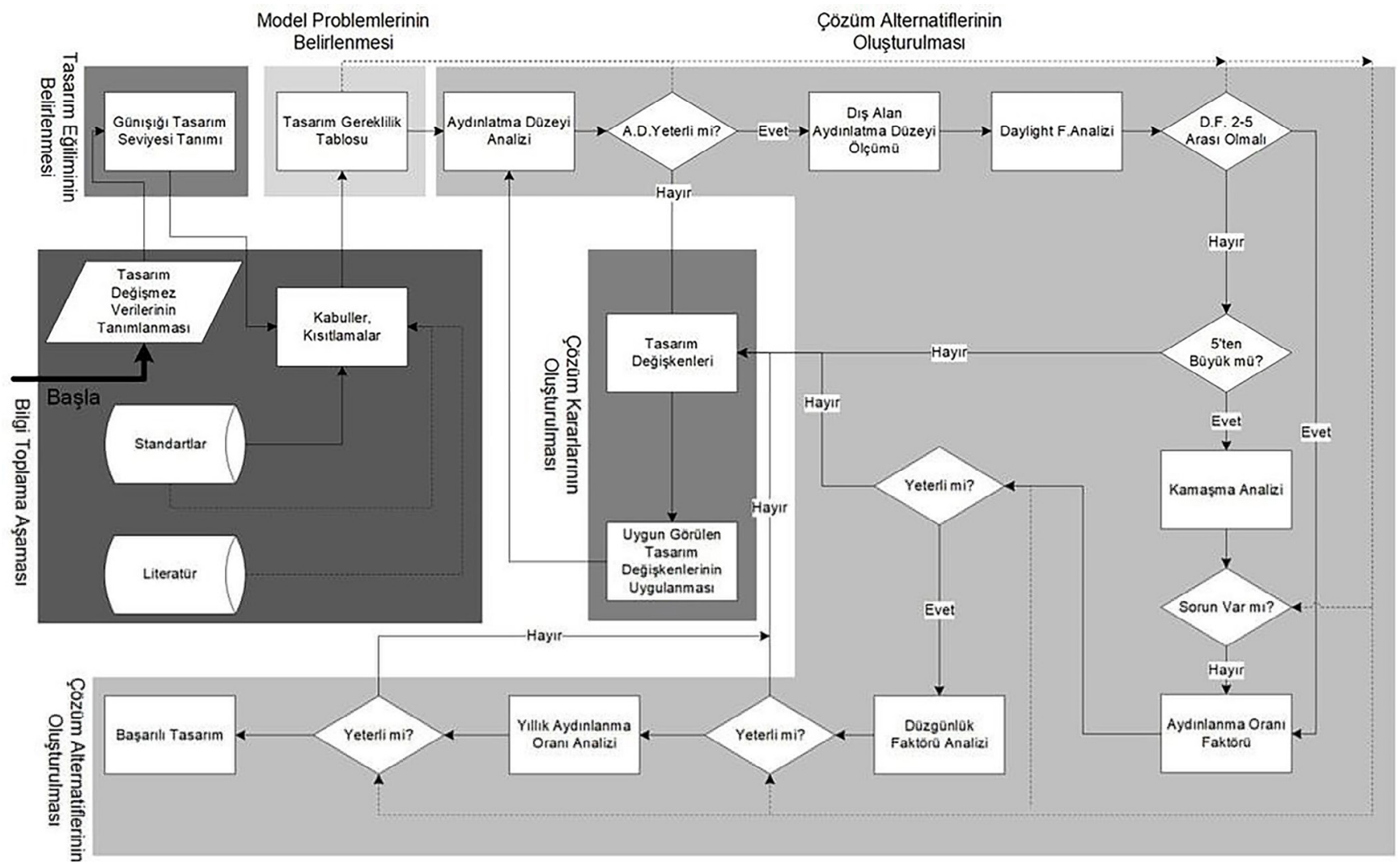

\subsection{Günışığı Destek Modeli Akış Şeması}

Geliștirilen model, akıș șemasında görüleceği üzere, hiyerarşik beș aşama üzerine kurgulanmıștır (Resim 6):

- Bilgi Toplama Așamasi

- Kısıtlamaların ve Tasarım Eğiliminin Belirlenmesi Așaması

- Çözümleme (Analiz) ve Problemlerin Belirlenmesi Așaması

- Çözüm Alternatiflerinin Oluşturulması Așaması

- Çözüm Kararlarının Oluşturulması Așaması

Modelin ișleyiși șematik olarak Resim 6'da gösterilmektedir.

\subsubsection{Model Bilgi Toplama Aşamast}

Tasarımcı tasarım süreci içinde birçok ön karar oluşturmaktadır. Tasarım sürecinde alınmıș tüm kararlar ve süreçteki tasarımın durumunu içeren bilgiler model için girdi oluşturmaktadır. Bilgi toplama aşamasında "model-tasarım girdileri" iki grupta incelenmektedir. İlki, tasarım sürecinde değișmedi- ği, model akışı süresince de değişmeyeceği kabul edilen girdilerdir. İkincisi, tasarımcının tasarım sürecinde değiş̦tirebileceğii, müdahale edebileceği tasarım değişkenleridir. Tüm model girdilerinin düzenlendiği aşamaya "Bilgi Toplama Așaması" ismi verilmektedir. Bilgi toplama aşaması aşağıdaki başlıklar altına toplanabilmektedir.

- Tasarım Süreci Boyunca Değişmez Veriler

o Tasarımcıya Bağlı Olmayan Değișmez Veriler

o Tasarımcıya Bağlı Olan Değişmez Veriler

- Tasarım Süreci Boyunca Değișebilen Veriler

Tasarım evresinde, mekânın tasarım sürecinde değişkenlik gösterebilecek özellikleri, geliştirilen model için Değissken Model-Tasarım Girdileri'ni oluşturmaktadır. Bu değişken girdiler, aynı zamanda modelin günıșı̆̆ı problemlerine karşı ele aldığ 1 ve derecelendirdiği sorunlara öneride bulunduğu çözüm alternatiflerini oluşturmaktadır. 
Değișmeyen girdiler ise model çözümleme aşaması için hazırlanan Tasarım Gereklilik Tablosu'nu oluşturan girdilerdir. Örnek vermek gerekirse, bir tasarımın bulunduğu konum, iklim, ișlev gibi verilerin tasarım süreci boyunca değişmeyeceği ama tasarımın sorunlarının belirlenmesi için de kullanılacağı kabul edilmelidir.

\subsubsection{Tasarım Önceliklerinin \\ Belirlenmesi ve Kıstasların Oluşturulması Aşaması}

Modelin akış șemasında, Resim 6'da görüldüğü gibi ilk aşamada tasarımcı bir işlev tanımı yapmaktadır. Tasarım için değişken olmayan ama çözümleme aşamasını ve "Tasarım Gereklilik Tablosu" nu etkileyen verilerin giriși ve tanımlaması yapılmaktadır. Model gerekli standartlar, yönetmelikler, bazı durumlarda ise günısıı̆ı literatürüne bağlı kalarak bir Tasarım Gereklilik Tablosu olușturur. Burada tasarımcının eğilimlerini de dikkate almak yararlı olacaktır. Tasarımcı kimi zaman daha yüksek seviyede günışığı çözümü beklerken kimi zaman da gerekliliklerle yetinmektedir.

Işleve göre Günışı̆̆ı Kriterleri tasarım öncelik seviyeleri.
$\mathrm{Bu}$ durumu örnek ile açıklamak gerekirse, bir okul yapısında sınıfların tasarımı ele aldığında, bazı tasarımcılar yüksek önceliği günıșığı ve konfora verirken, bazıları bu kriterleri aynı derecede öncelikli bulmamaktadır. Bu durumun birçok sebebi vardır fakat bu konu ele alınan modelin kapsamı dıșındadır. Model, bu tasarım seviyesi farklılıklarını bir tasarım gerçeği kabul ederek, Günışığı Kriterleri için tasarım öncelik seviyelerini belirlemiștir.

Tablo 5'te, en düşük seviye 1 en yüksek seviye 5 olarak ifade edilmek üzere, 1-5 aralığında derecelendirme yapılarak belirlenen ișlevler için öncelikli olması gereken Günışığı Kriterleri belirlenmiștir. Tasarım aşamasında hangi seviyelerin dikkate alınacağını belirlemek için 3 Tasarım Seviyesi oluş̧urulmuştur.

- A Tasarım Seviyesi (Seviye no 2, 3, 4 ve 5 için): Tamamen Günışığına Bağlı Tasarım

- B Tasarım Seviyesi (Seviye no 3, 4 ve 5 için): Aktif Günışı̆̆ Tasarımı

- C Tasarım Seviyesi (Seviye no 4 ve 5 için): Standart Tasarım

Tasarım seviyelerinin çeşitlenmesi amaca yönelik günışığı çözümlerine destek

\begin{tabular}{|c|c|c|c|c|c|c|}
\hline İŞLEV & $\begin{array}{l}\text { GÜNIŞIĞINA } \\
\text { BAĞLI } \\
\text { AYDINLIK } \\
\text { DÜZEYİ }\end{array}$ & $\begin{array}{l}\text { GÜNISSIĞI } \\
\text { FAKTÖRÜ }\end{array}$ & $\begin{array}{c}\text { GÜNIŞIĞINA } \\
\text { BAĞLI } \\
\text { KAMAŞMA }\end{array}$ & $\begin{array}{l}\text { GÜNIŞIĞINA } \\
\text { BAĞLI } \\
\text { AYDINLANMA } \\
\text { ORANI }\end{array}$ & $\begin{array}{l}\text { GÜNIŞIĞINA } \\
\text { BAĞLI } \\
\text { DÜZGÜNLÜK } \\
\text { FAKTÖRÜ } \\
\text { HOMOJENITE }\end{array}$ & $\begin{array}{c}\text { GÜNIŞIĞINA } \\
\text { BAĞLI YILLIK } \\
\text { AYDINLANMA } \\
\text { ORANI }\end{array}$ \\
\hline Okul (Derslik) & 5 & 5 & 5 & 5 & 5 & 5 \\
\hline Ofis (Çalışma Mekanları) & 5 & 5 & 5 & 5 & 5 & 5 \\
\hline Konut (Yaşam Alanı) & 4 & 3 & 2 & 3 & 2 & 3 \\
\hline Fabrika (Üretim Alanı) & 2 & 2 & 4 & 2 & 2 & 2 \\
\hline Müze (Sergi Alan1) & 2 & 2 & 4 & 1 & 2 & 1 \\
\hline Tiyatro (Salon) & 1 & 1 & 1 & 1 & 1 & 1 \\
\hline Çok Amaçlı Salon & 3 & 3 & 3 & 2 & 2 & 3 \\
\hline Spor Salonu (Saha) & 3 & 3 & 4 & 3 & 4 & 3 \\
\hline Dini Yapı (İbadet Alanı) & 2 & 2 & 1 & 1 & 1 & 2 \\
\hline İmalathane (Atölye) & 3 & 2 & 4 & 2 & 3 & 2 \\
\hline Restoran (Yemek Alanı) & 4 & 3 & 3 & 3 & 3 & 3 \\
\hline Kütüphane(Okuma Salonu) & 4 & 4 & 5 & 3 & 3 & 3 \\
\hline Hastane (Hasta Odası) & 5 & 5 & 3 & 4 & 4 & 4 \\
\hline
\end{tabular}


olmaktadır ve gereksiz zaman kayıplarını önlemektedir. Kabul edilmelidir ki tasarımc1 için tasarımda günışı ğ 1 konularından farklı problemlerde vardır. Böylece bilgi toplama aşamasında tasarımcıya bağlı değişmez verilerden biri olarak tasarım seviyesi, gereklilikler tablosu aşamasını etkilemektedir.

Gereklilik Tablosu, tasarımcının fiziksel çevre eğilimine, yapının bulunduğu iklim bölgesi, yapının işlevi ve yönlenmesine göre farklı kısıtlamaları içerir. Bu değișken ve oldukça geniş veri tablosu, tasarımcı için değerlendirme yapmayı kolaylaștırmaktadır. Her tasarımın farklılığını ön gören ve tasarımcı ile etkileșimli olarak fiziksel çevre eğilimini belirleyen model, her eğilim seviyesine göre farklı veri oluşturmaktadır. Modelin bu yönü ülkeye ya da iklimsel bölge çeșitliliğine göre değișebilir niteliktedir.

Ayrıca işlevsel farklılık ve gereklilikler de modelde ele alınarak tasarımcı için yol gösterici tanımlamalar yapılmaktadır. Model kapsamında, ilgili işlevin temel birimleri ele alınmakta ve kompleks projelerin, kendi içindeki ișlevsel farklılıklara göre modeli birçok defa kullanarak tasarımın alt mekanlarına daha doğru çözüm üretecekleri kabul edilmiştir.

\subsubsection{Model Çözümleme ve Problemlerin Belirlenmesi Aşamast}

Çözümleme verilerinin değerlendirilebilmesi için her aşamada Gereklilik Tablosuna ihtiyaç vardır. Gereklilik Tablosu çözümleme sonucunda olușan veri için olması gereken sınır değeri tanımlayan tablodur. Sorgulama sonucunda, öngördüğü sınır değerleri karșılayamayan faktörler "Çözülmesi Gerekli Sorun" olarak kaydedilir.

Modelin bu aşamasında, tasarımın günışığı kriterlerine göre analiz edilmesi ve olası problemlerin belirlenmesi gerekmektedir. Olușturulan model kurgusal bir model olduğundan dolayı analiz yazılımlarının gelișebileceğini ve değișebileceğini kabul eder. Günümüzde, BIM (Building Information Modeling) sürecine dâhil yeni nesil tasarım programları ile analiz sonuç verileri kolay elde edilebilmektedir.
Çözümleme aşamasında, tasarım ile ilgili analiz sonuçlarının alınabilmesi için ilk önce tasarımın analiz yapılabilecek üç boyutlu modelinin olup olmadığ tarafından sorgulanmaktadır. Bu aşamada hazır bir üç boyutlu model yok ise analiz sonuçlarının alınabilmesi için üç boyutlu modelin hazırlanması öngörülmektedir.

Daha sonra tasarım içinde bulunan mekânlar değerlendirilerek, model için analiz sonuçlarının alınacağı karar mekânları belirlenmektedir. Bu aşamada tasarım için önemli olan ve tasarıma yön veren mekânlar değerlendirmeye alınmaktadır. Hazırlanan model istendiği takdirde proje içindeki tek bir mekân için de çalışabilmektedir. Örnek vermek gerekirse, okul ișlevli bir mimari projede sınıflar, projenin içindeki diğer mekânlardan öncelikli olarak değerlendirilmek istenebilir.

Faktörlerin kendi içindeki hiyerarşik yapısı şu şekilde açıklanabilir: Mekân kalitesi düşünüldüğünde, Günıșığı Etkinliği Modülü'nün altı faktöründen ilk akla gelen Aydınlık Düzeyi'dir. Aydınlık düzeyinin yeterli olmadığı bir mekânda, günışı̆̆ 1 düzgünlüğünün ya da kamașma probleminin tasarımcı için daha düşük seviyede öncelikli olacağı öngörülmüştür.

Tasarımın üç boyutlu modeli bilgisayar ortamında fiziksel çevre analizlerinin yapılacağı formata getirildikten ve değerlendirilecek mekânlar belirlendikten sonra analiz sonuçları oluşturmaya başlanır. Oluşturulan modelde günışığının mekân iliş̧isini değerlendirmek için kriterler belirlenmiştir. Bu kriterlerin modelin uygulanması ve çözümleme aşamasında kullanımının kolaylaştırılabilmesi için aşağıdaki kabuller yapılmaktadır. Kriterlerin ve kriterlerin ölçütlerinin hatta özellikle çözümleme aşamasında kullanılan hesaplama ve belirleme yöntemlerinin zamana, olanaklara ve literatüre göre değișebileceği kabul edilmiștir. Bu yaklaşım ile model gelişebilir niteliktedir. Çözümleme aşamasında tasarımcının bu konuda uzman olmadığının kabul edilmesinden dolayı oluşturulan model bazı zor hesaplamalar yerine literatüre bağlı kabulleri esas almayı amaç edinmiştir (Tablo 6). Bu tasarıma ve 


\begin{tabular}{|c|c|}
\hline Günışığı Aydınlık Düzeyi & $\begin{array}{l}\text { TS EN 12464-1 standardına göre değerler kabul edilmiștir. Mekanın ortalama değerinin karşılaştırılması } \\
\text { kabul edilmiştir. Değerlerin en kötü dış aydınlık kabü̈ olan } 21 \text { Aralık saat } 12 \text { de kapalı hava şartlarında } \\
\text { hesaplanması öngörülmüştür. }\end{array}$ \\
\hline Günışı̆̆ı Faktörü & $\begin{array}{l}\text { Literatüre bağlı olarak \%2-5 aralığının yeterliliği kabul edilmiştir. Değerlerin en kötü dış aydınlık kabulü olan } \\
21 \text { Aralık saat } 12 \text { de kapalı hava şartlarında hesaplanması öngörülmüştür. }\end{array}$ \\
\hline Günışığına Bağlı Kamaşma & $\begin{array}{l}\text { Literatüre bağlı olarak Günışığı Faktörünün \%5 in üzerine çıkması durumunda kamaşma olma ihtimali kabulü } \\
\text { öngörülmüştür. Kamaşma hesaplamaları uzman yazılım ve donanım gerekmesinden dolayı bu kriter kabul } \\
\text { üzerinden yapılandırılmaktadır. Gerekli destek sitemlerinin tasarımcıda bulunması halinde analiz edilerek } \\
\text { sorun belirlenmesi tavsiye edilmektedir. }\end{array}$ \\
\hline Günıșığına Bağlı Aydınlanma Oranı & $\begin{array}{l}\text { Literatüre bağlı olarak standartlarda gerekli görünen aydınlık düzeyi şartlarını mekanın \% } \% 0 \text { inin sağlaması } \\
\text { gerektiği ve } 21 \text { Aralık saat } 12 \text { de kapalı hava şartlarında hesaplanması öngörülmüştür. }\end{array}$ \\
\hline Günıșığı Düzgünlük Faktörü & $\begin{array}{l}\text { Literatüre bağlı olarak mekan içindeki aydınlanma faklılıklarının eşitlenmesi yada minimuma indirilmesi için } \\
\text { mekanın üç noktasından alınacak ölçümlerin farklarının \%30 u geçmemesi öngörülmüştür. Bu değer projeye } \\
\text { ve tasarımcıya göre değişebilir nitelikte kabul edilebilir. }\end{array}$ \\
\hline Günıșığı Yıllık Aydınlanma Oranı & $\begin{array}{l}\text { Literatüre bağlı olarak dış aydınlığın bulunduğu yılın tüm zamanlarında mekanın aydınlık yeterliliğinin \% } 80 \\
\text { in üzerinde olması öngörülmüştür. } \\
\text { Mekanın tüm kullanım saatlerinin hesabı gerekmekte olduğu için hesaplanamaması durumunda yılın en kötü } \\
\text { dış aydınlık seviyesinde üç kullanım saati kabul edilip hesaplama yapılabilir. Mekanın kullanıma başladığı } \\
\text { saat, öğlen ve genel kullanımın sona erdiği saat kabul edilebilir. }\end{array}$ \\
\hline
\end{tabular}

Tablo: 6

Modelin Çözümleme Aşamasında kullanılan kriterler, kabuller ve kıstaslar. sürece göre gerektiğinde değișebilir ve gelișebilir bir yaklaşımdır.

\subsubsection{Model Tasarım Değişkenleri ve Çözüm Kararlarının Oluşturulması Aşaması}

Geliștirilen model, belirlenen sorunların her biri için çözüm alternatifi hesaplamak yerine oluşan sorunlar bütününü çözmek için en uygun çözüm alternatifi kümesini oluşturacak şekilde tasarlanmıştır. Geliştirilen model sorunlara bütünleşik çözüm aramaktadır. Bu durum tasarım aşamasının karakteristik özelliklerindendir. Tasarımc1 öngördügü ya da belirlediği tasarım problemlerini çözmek için en mantıksal ve pratik yolu seçmek, aramak zorundadır.

\subsubsection{Tasarım Değişkenleri}

Belirlenen sorunlara karşı modelin olușturacağı çözüm önerileri "Model-Tasarım Değişken Girdileri”'inden oluşmaktadır. Bu girdiler tasarımcının günıșığı konularında tasarımda değiştirebileceği tüm kantitatif özellikte mekânsal değişkenleri içerir.

- Pencere Oranı: Cephenin saydam yüzey alanının opak yüzey alanına oranıdır. Cepheye bağlı tasarım faktörlerinden pencere oranı, Günışı̆ğ Düzgünlük Faktörü dışında tüm günışı̆̆ kriterlerini etkileyen bir değişkendir.

- Pencere Biçimi: Cephede, pencere oranı ve konumu sabit tutularak uygulanan farklı pencere biçimleri, mekânın farklı bölümlerindeki aydınlık düzeyi dağılımında değişiklik göstereceğinden Tasarım Destek Modelinin değișkeni olarak günıșığ kriterlerini etkilemektedir.

- Pencere Konumu: Pencere oranı ve biçimi sabit tutularak pencerenin cephedeki konumunun değiștirilmesi, mekâna giren günıșığını farklı bölgelerde yoğunlaştıracağından tüm günışığı kriterlerini etkilemektedir.

- Çatı Penceresi: Tasarım Destek Modelinde; çatı penceresinin pencere oranı, biçimi ve konumundan bağımsız olarak tasarımda kullanılıp kullanılmamasının yarattığı etki hesaba katılmaktadır. Tasarımda kullanılması durumunda mekâna giren günışığını büyük oranda arttıracağından günışığı kriterlerinin değerlerini önemli ölçüde değiştirebilir.

- Cam Geçirgenlik Yüzdesi: 380 - 780 nanometre dalga boyları arasındaki görünür güneș ıșığının camdan geçiş yüzdesi olarak tanımlanmaktadır (Şenkal Sezer, 2005). Cephede cam günıșı̆̆1 geçirgenlik yüzdesi yüksek ya da düşük camlar kullanılması mekâna giren günışığı miktarını değiștirmekte ve günıșığı kriterlerini etkilemektedir. 
- Gölgeleme Elemanı: Gölgeleme elemanının iç mekandaki Aydınlık Düzeyine, anlık ve Yıllık Aydınlanma Oranına ve Günıșı̆ğ Faktörüne etkisi azdır. Ancak Kamașmayı engelleyen önemli bir unsur olduğundan tasarım girdisi olarak ele alınabilir.

- Ișı̆̆ı Etkileyen Peyzaj: Peyzaj öğeleri diş mekânda yer alsa dahi iç mekân ile aralarında her türlü aydınlık yüzeyini etkileyen unsurlara sahiptir. Özellikle odunsu gövdeli köklü bitkilerin, yıllık yaprak dökme ve yaprak açma döngüsü sebebiyle iç mekânda yıl boyunca değişen aydınlık oranını etkiler.

- Zemin ve Tavan Tipi: Zeminin ve tavanın formu, dokusu, yüzey kaplama malzemesi, yüzeye düşerek yansıma yapacak günışığını etkileyen her türlü form, mimarideki aktif günışığı oranını etkiler. Söz gelimi, tavan kaset döșeme olabilir ve formundaki girinti çıkıntılar gölgelendirilmiş alanların oluşmasına yol açabilir.

- Öteleme Teknolojileri: Aynalama sistemleri olarak da bilinen bu teknolojiler sayesinde diş mekandaki günışığını içeride en köșe noktalara kadar almak mümkündür. Ayna gibi yansıtıcı yüzeyler aracılığı ile günışığı yönlendirilerek iç mekâna yayılabilir. Öteleme teknolojileri, Yıllık Aydınlanma Oranı'nı, Günıșı̆̆ı Düzgünlük Faktörü’nü ve Kamaşma'yı doğrudan etkiler.

- İç Mekân Rengi: İç mekânın rengi, iç mekandaki aktif günıșığını ortalama değerlerin üzerinde etkileyen bir role sahiptir. Renk, günıșı̆̆ını yansıtıcı veya absorbe edici özelliği nedeniyle günışığı tasarım girdisi olarak ele alınabilir.

- Tefriş: İç mekânda bulunan sabit ve hareketli mobilyalar, taşınmazlar ve diğer her türlü tefriș tanımına girecek dekoratif unsur, iç mekânın aydınlanma oranını ortalama düzeyde etkileyecektir. İç mekânın farklı noktalarının aydınlanmasını etkileyen unsurları olușturur.

\subsubsection{Tasarım Değgişkenleri İle Günışı̆̆ı Kriterlerinin İlişsisi}

Mimarın tasarımı için düşünebileceği tüm tasarım değişkenleri ile belirlenen sorunlar arasında matematiksel ve mantıksal bir ilişki vardır. Tecrübeli bir mimar, tasarım evresinde özellikle fiziksel çevre konuları için bu mantıksal ilişsiyi kullanarak çözüm oluşturur ya da tasarımında değişiklik yapma kararı verir.

Daha da açıklamak gerekirse model, kriterler arasında hiyerarşik bir yapıda sıralı analiz yapmasına rağmen çözüm alternatiflerinin oluşturulması sırasında diğer kriterlerde sorun olduğu zaman, bütünleșik çözüm olacak seçeneğe öncelik vermektedir. Tasarımcı daha önceden uzmanlar tarafından belirlenmiș ve ilișki puanlamas1 yapılmış çözüm alternatifleri içinden çözümü değerlendirir. Çözüm önerileri, tasarımın farklı sorunlarının ya da şartlarının olduğu kabulü ile tasarımcı tarafindan değerlendirilir.

Tablo 7'deki “İlișki Tablosu”, Günışı̆̆ Faktörleri ile "Model - Tasarım Değișken Girdileri" arasındaki ilișkiyi göstermektedir. Bu nedenle model ilk önce İlișki Tablosu'nu kullanarak tüm model-tasarım değişken girdileri içinden çözüm olabilecek alternatifleri oluşturur. Bir mimari tasarımda, belirlenen sorunlara karşı, sorunlar ile ilișkili kriterlerin hiyerarșik yapısı tasarımcının oluşturduğu çözüm kararını etkilemektedir.

Modeldeki hiyerarşi ve tasarım değişkenleri ile kriterler arasındaki çözüm ağırlıkları, 3.2. bölümde açılanan uzman görüșü yöntemi ve alanda çalışan tecrübeli uzmanlar ile yapılan toplantılar sonucunda, konuların tartışılarak doldurulduğu anket formları ile belirlenmiștir. Tabloda yer alan seviyeler en düșük 1 , en yüksek 5 ile ifade edilmiş ve 1-5 aralığında derecelendirme yapılarak seviyeleri belirtilmiștir.

Modelde günışığı faktörlerinin hiyerarşik yapısının, projeye ve tasarımcıya özgü farklılıklar gösterebileceği gibi genelleme yapılarak mantıksal bir önem sıralamas1 dâhilinde de ele alınabileceği kabul edilmiştir. İstenildiği takdirde tasarımcının isteği doğrultusunda çözüm ağırlıklarının 


\begin{tabular}{|c|c|c|c|c|c|c|c|}
\hline $\begin{array}{c}\text { CEPHEYE } \\
\text { BAĞLI } \\
\text { FAKTÖRLER }\end{array}$ & $\begin{array}{l}\text { GÜNIŞIĞINA } \\
\text { BAĞLI } \\
\text { AYDINLIK } \\
\text { DÜZEYİ }\end{array}$ & $\begin{array}{l}\text { GÜNIŞIĞI } \\
\text { FAKTÖRÜ }\end{array}$ & $\begin{array}{l}\text { GÜNIŞIĞINA } \\
\text { BAĞLI } \\
\text { KAMAŞMA }\end{array}$ & $\begin{array}{l}\text { GÜNIŞIĞINA } \\
\text { BAĞLI } \\
\text { AYDINLANMA } \\
\text { ORANI }\end{array}$ & $\begin{array}{l}\text { GÜNIŞIĞINA } \\
\text { BAĞLI } \\
\text { DÜZGÜNLÜK } \\
\text { FAKTÖRÜ } \\
\text { HOMOJENITTE }\end{array}$ & $\begin{array}{c}\text { GÜNISSIĞINA } \\
\text { BAĞLI YILLIK } \\
\text { AYDINLANMA } \\
\text { ORANI }\end{array}$ & TOPLAM \\
\hline Pencere Oranı & 5 & 5 & 4 & 4 & 2 & 5 & 25 \\
\hline Pencere Biçimi & 4 & 4 & 3 & 3 & 2 & 3 & 19 \\
\hline Pencere Konumu & 3 & 3 & 3 & 4 & 3 & 3 & 19 \\
\hline Çatı Penceresi & 5 & 5 & 3 & 5 & 4 & 5 & 27 \\
\hline $\begin{array}{c}\text { Cam Geçirgenlik } \\
\text { Yüzdesi }\end{array}$ & 3 & 3 & 3 & 3 & 1 & 3 & 16 \\
\hline $\begin{array}{l}\text { Gölgeleme } \\
\text { Elemanı }\end{array}$ & 1 & 1 & 5 & 1 & 4 & 1 & 13 \\
\hline $\begin{array}{l}\text { Işığı Etkileyen } \\
\text { Peyzaj }\end{array}$ & 2 & 1 & 3 & 2 & 1 & 4 & 13 \\
\hline Zemin ve Tavan & 3 & 4 & 3 & 4 & 4 & 4 & 22 \\
\hline $\begin{array}{c}\text { Öteleme } \\
\text { Teknolojileri }\end{array}$ & 1 & 1 & 5 & 4 & 5 & 5 & 21 \\
\hline İç Mekan Renk & 3 & 3 & 4 & 4 & 4 & 4 & 22 \\
\hline Tefriş & 3 & 3 & 3 & 3 & 4 & 3 & 19 \\
\hline
\end{tabular}

Tablo: 7

Tasarım Değişkenleri ve Günışı̆ı Kriterleri Ilişki tablosu. hesaplandığı hiyerarşik yapı değișebilir niteliktedir. Fakat geliştirilen modelin ana kurgusu olarak, günışığı tasarımı konusunda tasarımciya destek verilmesi kabulü ile genel bir hiyerarşi oluşturulmuştur.

\subsubsection{3 Çözüm Kararlarının Oluşturulması}

Geliştirilen model, çözüm önerilerinin hesaplanması için günışığı konusunda tecrübeli tasarımcıların oluşturdukları değer kararlarını kullanarak tasarım davranışını modellemektedir. Tasarımcı model sonucunda çıkan çözüm ağırlıklarını değerlendirerek tasarımına en uygun çözüm kararını oluşturur.

Geliștirilen Model, "Model-Tasarım Değişkenleri'nin çözüm ağırlıklarını belirledikten sonra en uygun çözüm alternatif kompozisyonunun oluşturulması için tasarımcı ile etkileşimli bir işlem yürütmektedir. Tasarımcı ile etkileşimli işlem sürdürülmesinin nedeni, tasarımcının belirlenen çözüm alternatifleri arasından, çözüm ağırlıklarını değerlendirerek kendi seçim yapma özgürlüğünün sağlanmasıdır. Ayrıca modelin önerdiği çözüm kararları özellik niteliğindedir. Bu nedenle modelin özelliği tasarımcıya kendi kararlarını oluşturabilme ve bu kararlara göre tasarıma en uygun sonuç uygulamayı seçme imkânı vermektedir.

\subsubsection{Akış Şeması Tasarım Döngüsü}

Geliştirilen model bir Tasarım Destek Sistemi'dir. Modelin önerilerini tasarımcı değerlendirmektedir. Tasarımcı istediği takdirde modeli, tasarım evresinin istediği bir aşamasında yeniden kullanabilir. İsterse kompleks bir projede proje kapsamındaki mekanlar için ayrı ayrı da modeli çalıştırabilir.

\section{Aktif Günışı̆̆ı Tasarım Destek Mode- linin Sinanmast}

Geliştirilen günışığı modelinin sınanması için, İstanbul' da bulunan, Milli Eğitim Bakanlığı'nın 12 derslikli tip lise projesi seçilmiştir (MEB, n.d.-a) (Resim 7). Millî Eğitim 


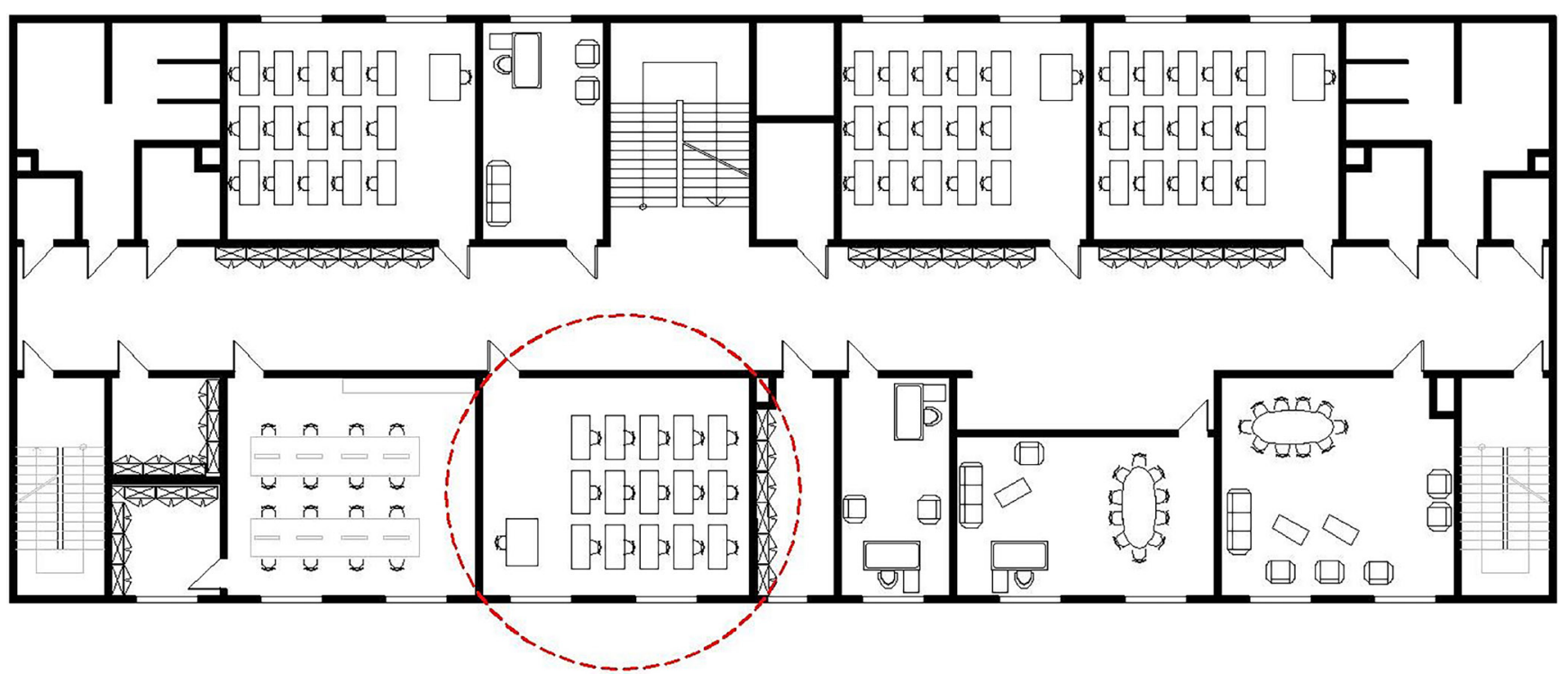

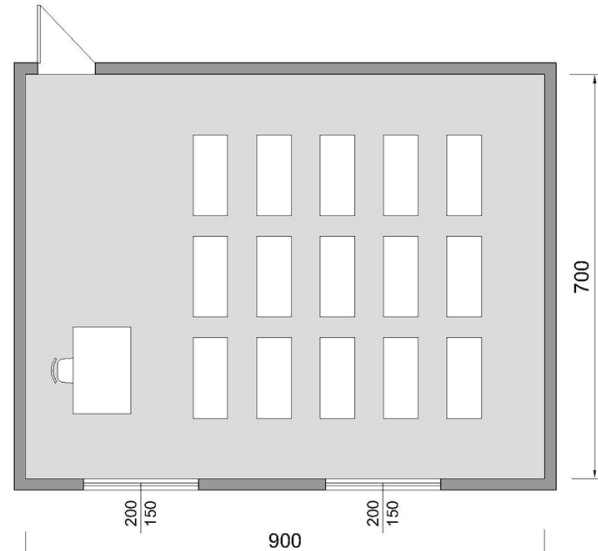

Bakanlığı'nın yeni proje hedefleri arasında, okullardaki fiziki koşulların iyileștirilmesi yer almaktadır. Bakanlık birçok yeni proje geliştirmiştir. Bu projeler içinde yaygın kullanımı olacağı düşünülen örneklem üzerinden gidilmiștir ( $M E B$, n.d.-b).

Modelin sınanması için, Resim 7'deki tip okul projesinin güney cephesinde konumlandığı kabul edilen, yaklaşık $9,00 \mathrm{~m}$ x 7,00m boyutlarındaki derslik kullanılmıştır. 2 adet penceresi bulunan sınıfın pencerelerinin boyutlar $2,00 \mathrm{~m} \times 1,50 \mathrm{~m}(\mathrm{~h})$ dir. Sinıfta 15 adet sira ve 1 adet eğitmen kürsüsü bulunmaktadır (Resim 8 ve 9).

Oluşturulan kurgu modelde, sinamaya tasarım seviyesi seçilerek başlanmıştır. Tablo 5'te tasarım seviyelerinin işlevlere göre dağılımı gösterilmiştir. Millî Eğitim Bakanlığı'nın okullar için yüksek tasarım seviyesi seçmesine gerek olmadığ 1 düşünülmüş, standart tasarım seviyesinde (C Tasarım Seviyesi) okullar için tüm günışığ 1 kriterlerinin modele dahil olduğu tespit edilerek Tablo 8'deki kabuller belirlenmiștir.

Modelin söz konusu kriterler için analizleri, konunun bilgi seviyesi arttıkça daha farklılaşabilecektir. Ișığın yetersizliği kadar fazla olma durumu da tasarımda sorunlara neden olabilmektedir. Aydınlık Düzeyi analizleri için 21 Aralık gününün seçilmesinin sebebi, dış aydınlık seviyesi-

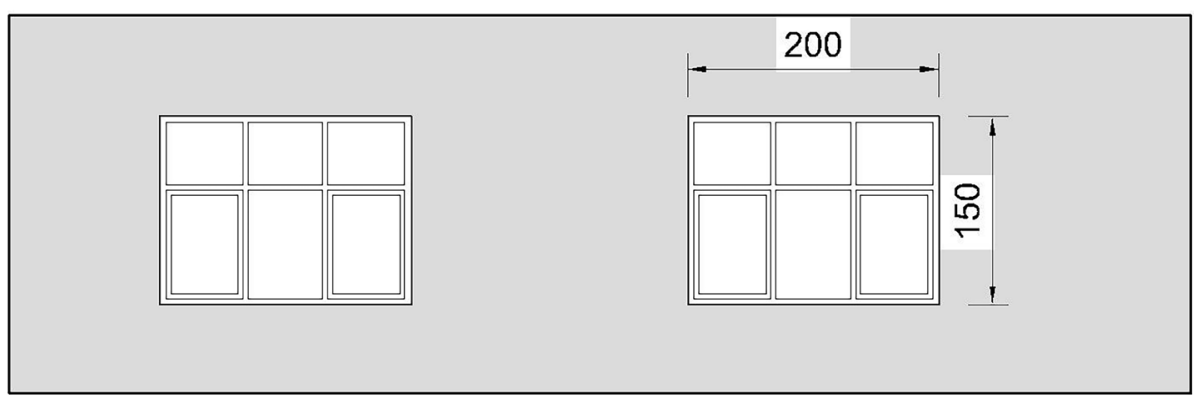

Resim: 7

Milli Eğitim Bakanlığı'nın 12 Derslikli Tip Lise Projesi planı (MEB, n.d.-b).

Resim: 8

Sinaması Yapılan Derslik Planı.

Resim: 9

Sinaması Yapılan Derslik Cephesi. 
Tablo: 8

Dersliklerde Modelin Çözümleme Aşamasında kullanilan kriterler, kabuller ve kistaslar.

Resim: 10

Ecotect Programinda Analiz Edilen Günışı̆̆ Aydınlık Düzeyi Değer Aralıkları.

\begin{tabular}{|l|l|}
\hline Günıșığı Aydınlık Düzeyi & Min ortalama 300 lux \\
\hline Günıșığı Faktörü & $\% 2-5$ aralığı \\
\hline Günıșı̆̆ına Bağlı Aydınlanma Oranı & $\% 80$ \\
\hline Günıșığına Bağlı Kamaşma & $\% 5$ den Küçük Günışığı Faktörü \\
\hline Günıșığı Düzgünlük Faktörü & Min \%30 Farklılık \\
\hline Günıșığı Yıllık Aydınlanma Oranı & $\% 80$ \\
\hline
\end{tabular}

nin görece daha düşük olması durumunda tasarımı ölçmektir.

Günışığı analizleri için ECOTECT Programı ve Radiance hesaplaması kullanılmıștır. Seçilen derslik Ecotect programında modellenerek, sınıfın günıșığ analizinde, kapalı gök koșularında, 21 Aralık günü, saat 12.00'ye göre hesaplamalar yapılmıștır.

Günışığı Kriterleri, seçilen derslik için Günışı ğı Tasarım Destek Modeli Akıș Șeması'ndaki akışa göre analiz edilmiștir. Model akışına göre öncelikle Günıșığı Aydınlık Düzeyi analizleri yapılmalıdır. Ecotect programında hesaplama düzlemi yerden 70 cm olarak belirlenerek Günıșığı Aydınlık Düzeyi analizi yapılmıștır. Analizlerin sonuçlarını veren analiz yüzeyinin boyama aralığ $1,0-10001 \mathrm{x}$ arasındadır ve kontur boyaması aralığı 100 birim olarak ayarlanmıștır. Yapılan analizde sınıfın ortalama aydınlık düzeyi 272 lx olarak bulunmuștur. Tasarım Gereklilikleri Tablosu'na göre (Tablo 8) aydınlık düzeyinin yetersiz olduğu saptanmıştır (Resim 10) (Autodesk, 2011).

Yapilan analiz sonucunda belirlenen soruna, modele göre tasarım değișkenlerinden yüksek etki oranına sahip olan çözüm bulunmaya çalıșılmaktadır. Seçilecek tasarım değişkeni iki aşamalı seçilmektedir. Oluşan sorun ile ilişkili etki oranı ve tüm faktörlere bağlı etki oranı değerlendirilmektedir. Öncelikle sorun için, faktör ile ilgili

\section{Daylight Analysis}

RAD Euminance

Contour Range: 0 - 1000 Lux In Steps of 100 Lux EECOIEGT v5

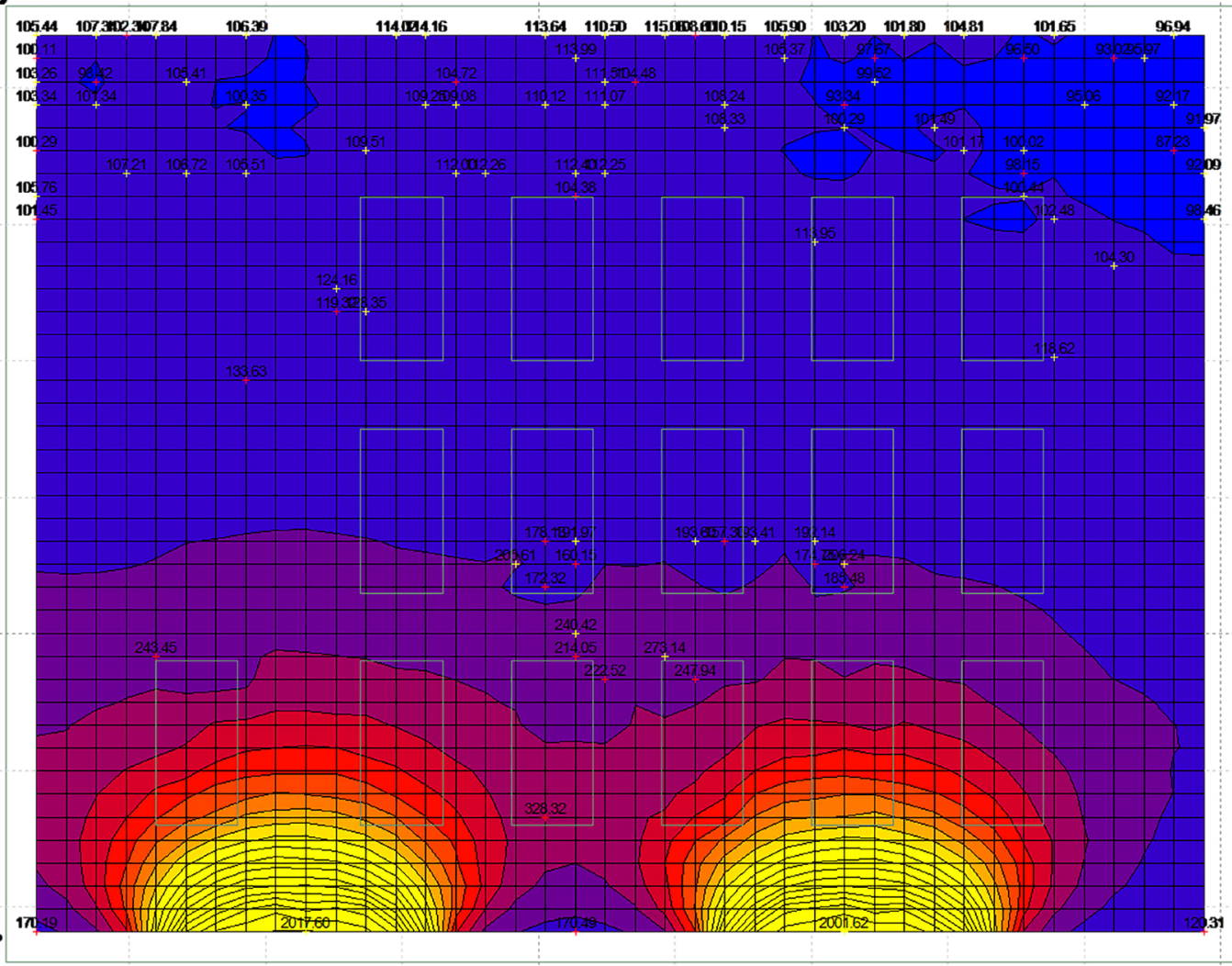




\begin{tabular}{|l|c|c|}
\hline Cepheye Bağlı Faktörler & Aydınlık Düzeyi Faktörü & Tüm Kriterlerin Toplam Etki Puanı \\
\hline Pencere oranı & 5 & 25 \\
\hline Pencere biçimi & 4 & 19 \\
\hline Çatı penceresi & 5 & 27 \\
\hline
\end{tabular}

Tablo: 9

Oluşan soruna bağlı seçilen yüksek öncelikli tasarım değiskenleri. yüksek ilişkili seçenekler değerlendirmeye alınmış ve bu seçenekler arasında tüm kriterlere etki puanı yüksek olan seçenekler tasarımcıya önerilmiștir. Fakat tasarımc1nın tasarımına bağlı olarak bu seçenekleri kendisinin seçeceği düşünülmüștür.

Tasarım değișkenleri ve Günıșığı Kriterleri İlişki Tablosu'nda (Tablo 7) aydınlık düzeyini en fazla etkileyen ve toplam etki puanı en yüksek olan tasarım değişkenleri Tablo 9' da değerlendirilmiştir.

Tabloya göre tasarımı yönlendirecek değişkenlerden çatı penceresi en yüksek etki oranına sahiptir. Ancak projenin kurgusunun çok katlı olmasından dolayı çatı penceresi açılamamakta ve bu seçenek seçilememektedir. İkinci en yüksek puan alan pencere oranı değișkeni tercih edilmiştir. Binanın cephe tasarımı kurgusunu bozmamak için, proje incelenip pencere modülünün diğer mekânlarda da aynı olması ihtimaline karşı, pencere modülünün biçimini değiștirmeden sayısının artırılmasına karar verilmiştir. Dersliğin cephesinde bulunan 2 adet pencere sayıs 3 adet olarak değiștirilerek model tekrar sınanmıștır (Resim 9 ve 11).

21 Aralık günü, saat 12:00 için 3 pencereli model kapalı gök koşullarında tekrar analiz edilmiștir. Ortalama aydınlık düzeyini 300 lx’e ulaştırmak amacıyla yapılan bu tasarım değişikliğinden sonra, Resim 12'de gördüğümüz 552,86 lx sonucu elde edilmiştir. Derslikler için bu sonuç uygundur ve modelin kendi akışına devam edilmiştir.

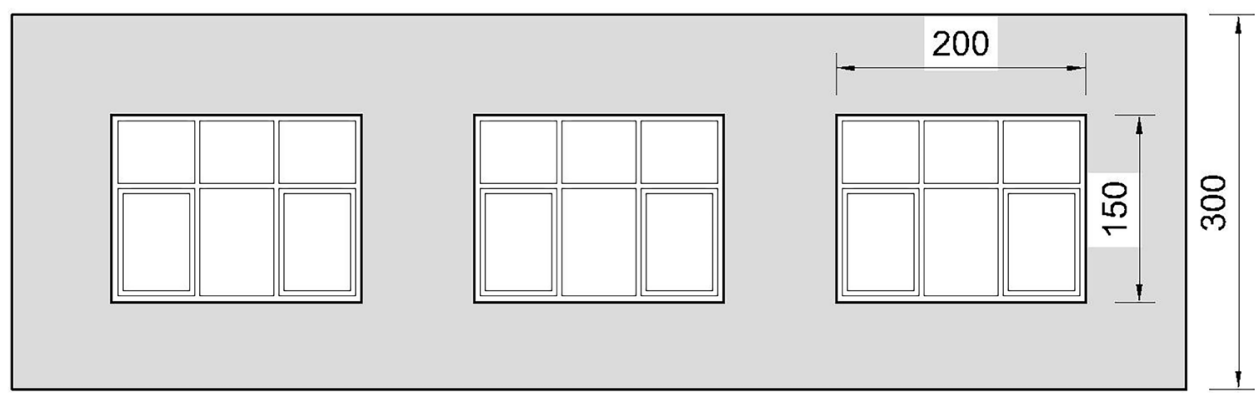

Modeldeki bir sonraki aşama olan diş alan aydınlatma düzeyi ölçümünü, analiz yapılan yazılım tipik yıl kullandığı için kendisi yapmaktadır. Analizlerde Ecotect programı ve hesaplama metodolojisi olarak Radiance hesaplaması kullanılmıștır (Autodesk, 2011).

Tasarım gereklilik tablosuna göre günışı̆̆1 faktörünün $(D F) \% 2$ ile $\% 5$ arasında olması gerekmektedir. Yapılan analiz sonucu DF \%3.97 çıkmıștır. Bu değer, modelde, bu aşamada gerekliliği sağlamaktadır. Modele göre \%2-5 arasında çıkan DF analizi kamaşma sorununa da neden olmadığı için Aydınlanma Oranı Faktörü analizi aşamasına geçilmiştir.

Aydınlanma Oranı Faktörü için oluşturulan model, ortalama gökyüzü şartlarında, 21 Aralık günü, saat 12:00 seçilerek analiz edilmiştir. Bu faktör ortalama gökyüzü analizi ile yapılmıştır. Yapılan hesaplamalar sonucunda aydınlanma oranı \%96.2 çıkmıştır. Bu değer Aydınlanma Oranı Faktörü için yeterlidir.

Bir sonraki faktör Düzgünlük Faktörü'dür. Düzgünlük Faktörü analizi için, ayarlanmış Aydınlık Düzeyi hesap yüzeyinden yararlanılarak, sınıfın pencere ve iç duvarindan bir metre mesafeden ve sinıfin orta noktasından alınan hesaplama değerleri arasındaki farklara bakılmıștır. Hesaplamalar sonucunda Resim 13'te görüldüğü gibi hesaplama sonuçları farklarının sınır değerleri aştığı ve sınıf için Düzgünlük Faktörünün sağlanması gerektiği sonucuna varılmıştır. 


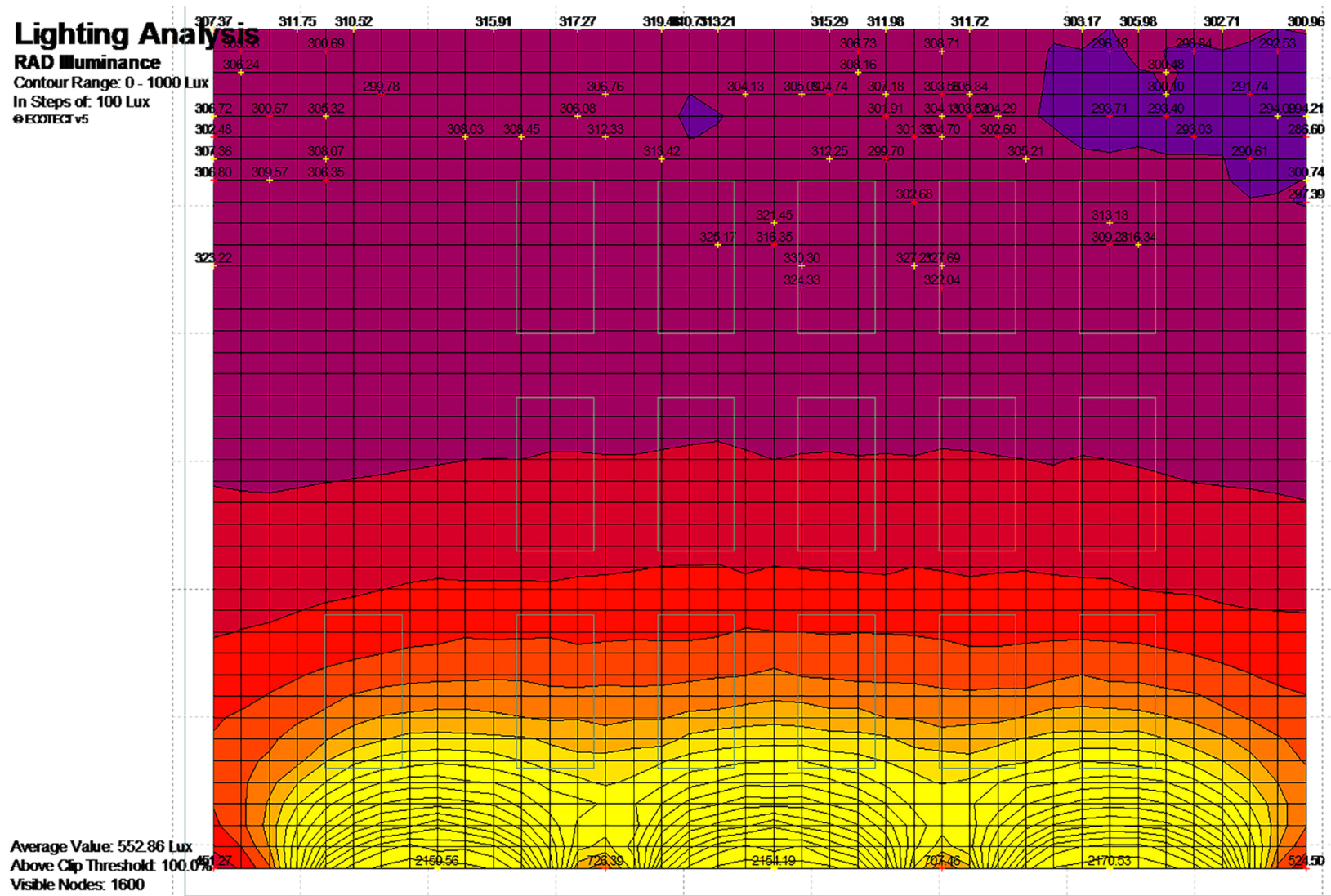

Resim: 12

Projedeki Pencere Modülü Arttırıldıktan Sonra Yapılan Analiz Sonucu.

Resim: 13

Günısı̆ı̆ Düzgünlük Faktörü Analizi.

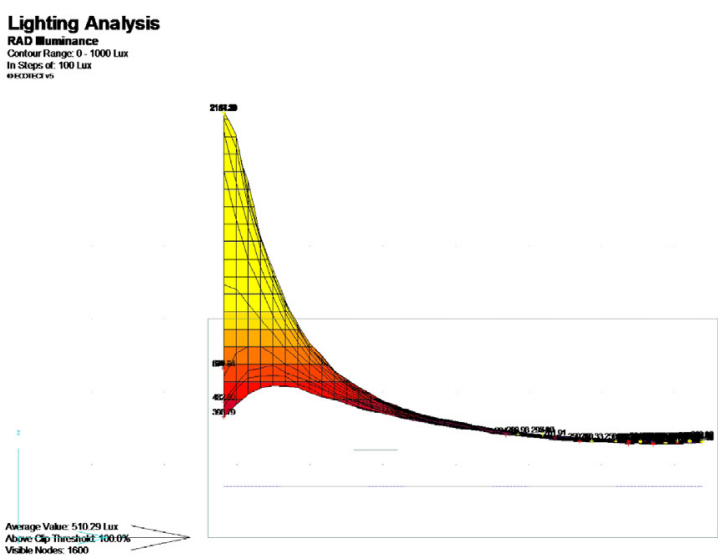

Yapılan analiz sonucunda belirlenen sorunun çözülmesi için modele göre tasarım değişkenlerinden yüksek etki oranına sahip değișkenin bulunması gerekmektedir. Tasarım değişkenleri ve günıșığı kriterleri ilişki tablosunda (Tablo 7) Düzgünlük Faktörünü en fazla etkileyen ve toplam etki puanı en yüksek olan tasarım değişkenleri Tablo 10'da değerlendirilmiştir.
Tablo 10'a göre tasarımı yönlendirecek değişkenlerden Öteleme Teknolojileri en yüksek etki oranına sahiptir ve tercih edilmiştir. Öteleme Teknolojileri kendi içinde değerlendirildikten sonra okul binaları için en uygun seçeneğin 1 şı rafi olduğu kararına varılmıștır.

Ișık rafı, günışığının verimli kullanılmasını sağlayarak enerji tasarrufu sağlayan, gelişmiş günıșığı aydınlatma sistemlerin- 


\begin{tabular}{|l|c|c|}
\hline Cepheye Bağlı Faktörler & Günıșığı Düzgünlük Faktörü & Tüm Kriterlerin Toplam Etki Puanı \\
\hline Öteleme Teknolojileri & 5 & 21 \\
\hline İç mekan Renk Değişimi & 4 & 22 \\
\hline Tefriş & 4 & 19 \\
\hline
\end{tabular}

Tablo: 10

Oluşan soruna bağlı seçilen yüksek öncelikli tasarım değiskenleri. dendir (Kurtay \& Esen, 2018). Ișık rafları cepheye sonradan monte edilebilen veya ilk tasarımda bir tasarım unsuru olarak cephe ile bütünleşmiş bir yapı elemanı olabilir. Genellikle diş cephede farklı örnekleri görülen cam rafı uygulamalarının, pencere içerisine bir ray üzerine monte edilen uygulamalarına rastlanmaktadır (Byun, Ryu, \& Kim, 2019).

Işık rafı uygulamaları camlardan gelen güneş ışığının engellenmesi veya yapı içerisinde yönlendirilmesi esasına dayanmaktadır (Yener, 2007). Pencerede göz hizasının üzerinde yer alan cam rafi, üst kısımdan 1şığın içeri alınmasını sağlayan yatay veya yataya yakın pozisyonda bulunabilmektedir. İç mekanda dengesiz aydınlık ve kamaşmanın önlenmesinde etkindir (Kim, Lee, Jang, Park, \& Choi, 2019). Özellikle çalışma mekanlarında ve okullarda çalışma konforunun sağlanmasında etkili olan ışık raflarının örnek okul günışığı analizinde tüm camlara uygulanarak pencere önündeki fazla ışığın içeri yansıtılarak mekânın derinindeki ışık oranının yükseltilmesi amaçlanmıştır. Pencereye iç veya dıştan monte edilebilen cam rafları, yansitıcıl1ğ1 yüksek malzemelerden veya işlenmiş alüminyumdan yapılmaktadır (Kazanasmaz, 2009). Analizde kullanılan ışık rafı, özel bir cam yüzeyden oluşmaktadır. Işık rafının üzerindeki kaplamanın 1şık yansıtma indeksi 6'dir.

Işık rafı uygulanmış modelde yapılan analizler sonucunda, model kurgusu gereği tüm faktörler yeniden değerlendirilmiștir. Hesaplama sonucunda Aydınlık Düzeyi ortalaması 654 lx olarak belirlenmiștir.
Resim: 14

Işık Rafı Uygulanmış Model Analizi.

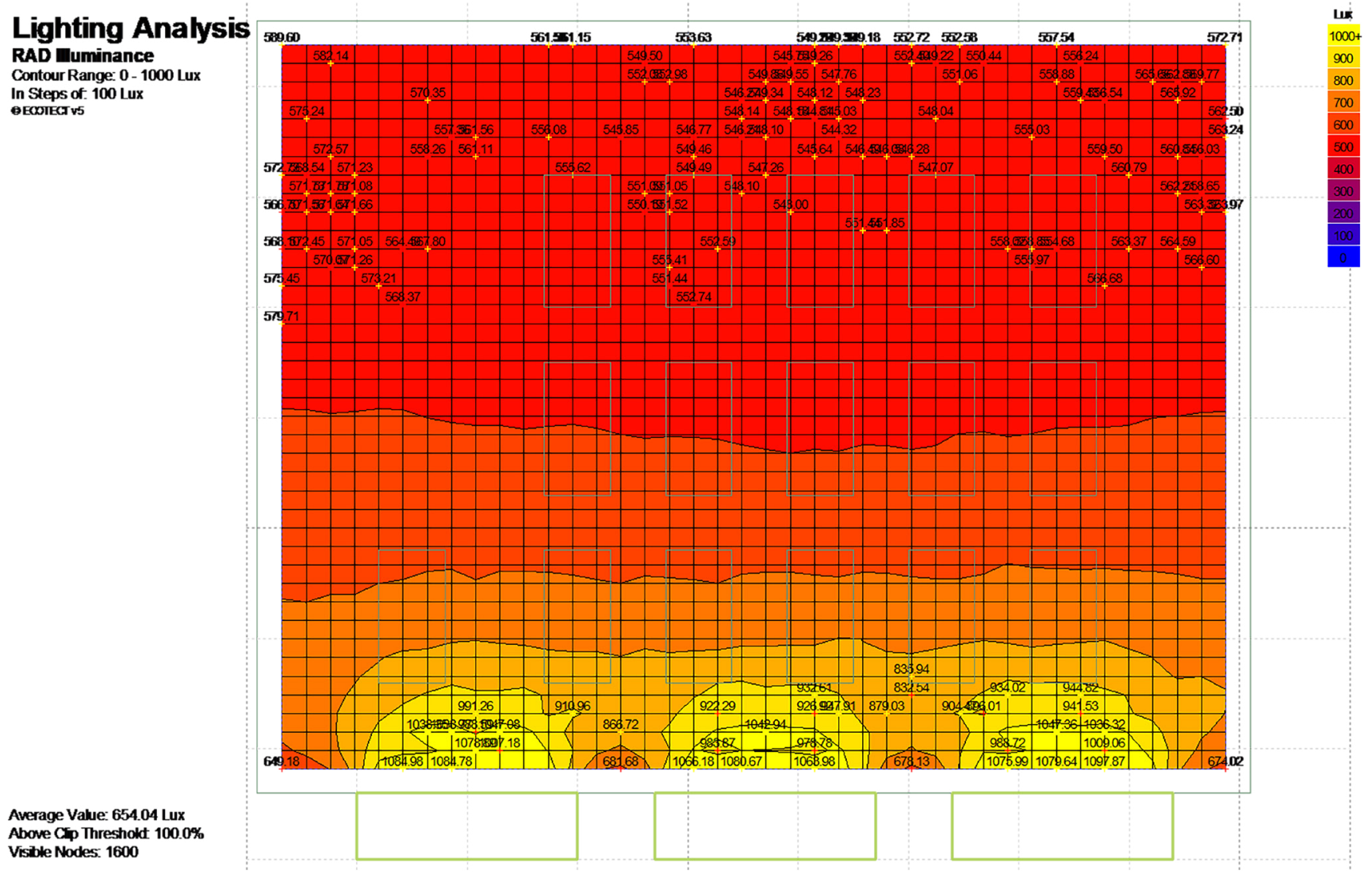


Resim: 15

Işık Rafı Uygulanan Modelin Günışı̆ı Düzgünlük Faktörü Analizi.

Resim: 16

Yıllık Günışı̆̆ı Aydınlanma Oranı Hesaplama Yazılımı.
Günıșığı Faktörü ortalaması ise 4.87 olarak hesaplanmıștır ve modele göre yeterlidir. Aydınlanma Oranı ise \%100 olarak bulunmuștur (Resim 14).

Böylece modele göre, daha önceden sorun olarak belirlenen Günışığı Düzgünlük Faktörü hesaplamaları yeniden yapıldığında, pencere önünde hesaplanan değerlerin düştüğü ve mekânın iç tarafında iki katına varan değer artışları olduğu saptanmıştır (Resim 15).

Yıllık Günışığı Aydınlanma Oranı çözümlemesi yapılan sınıf mekânında, en son 1şık rafı ile yapılan hesaplamalarda günıșığ 1 faktörü ortalaması ise 4,87 olarak bulun- muștur. Buna bağlı olarak așağıda, Resim 16 'da görülmekte olan yazılım kullanılarak Yıllık Günışı̆̆ı Aydınlanma Oranı hesaplanmıștır. Sınıf konfor değerlerine göre $\% 80$ oranını tutturmaktadır.

Tasarlanan kurgu modelin, bir okul binas1 içindeki bir sınıf birimi örneğinde sınanarak denenmesi neticesinde, 21 Aralık günü, kapalı hava şartları kullanılarak tüm revizyonları yapılmıș ve bu en kötü hava şartında bile günışığından maksimum yararlanma sağlanmaya çalıșılmıștır. Model, istenildiği taktirde, tasarım sürecinin herhangi bir aşamasında tekrar kullanılabilir. Uygun ölçüm cihazlarının bulunması durumunda, mevcut binalarda da günışığı
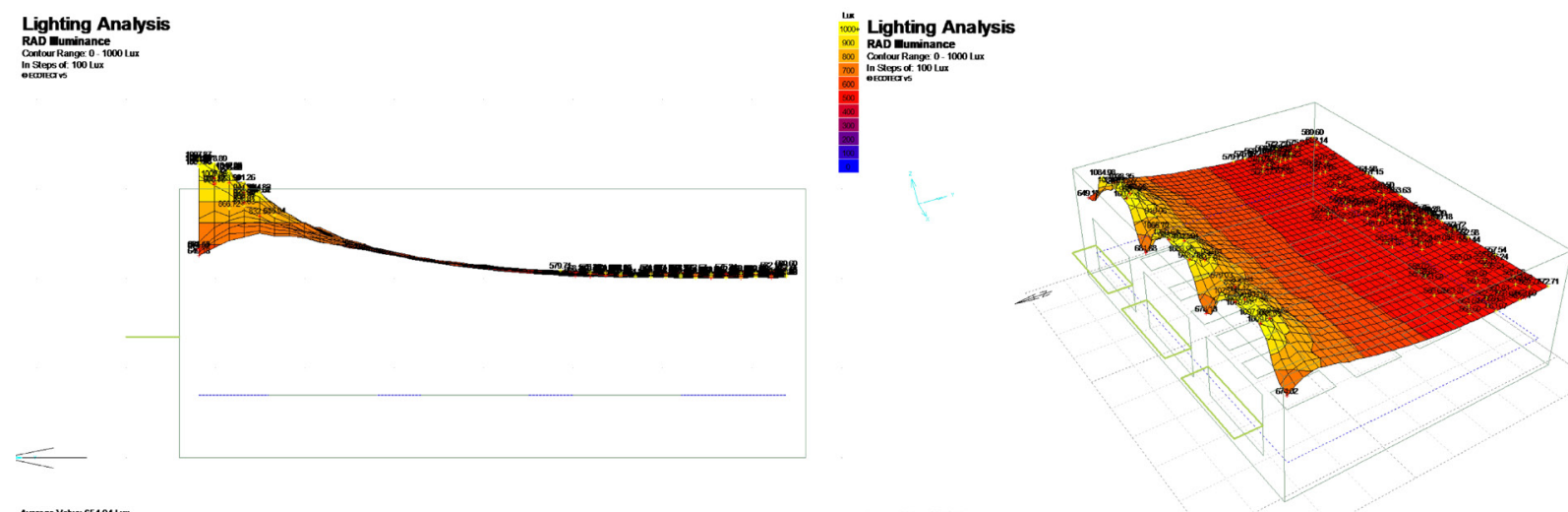

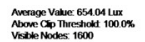
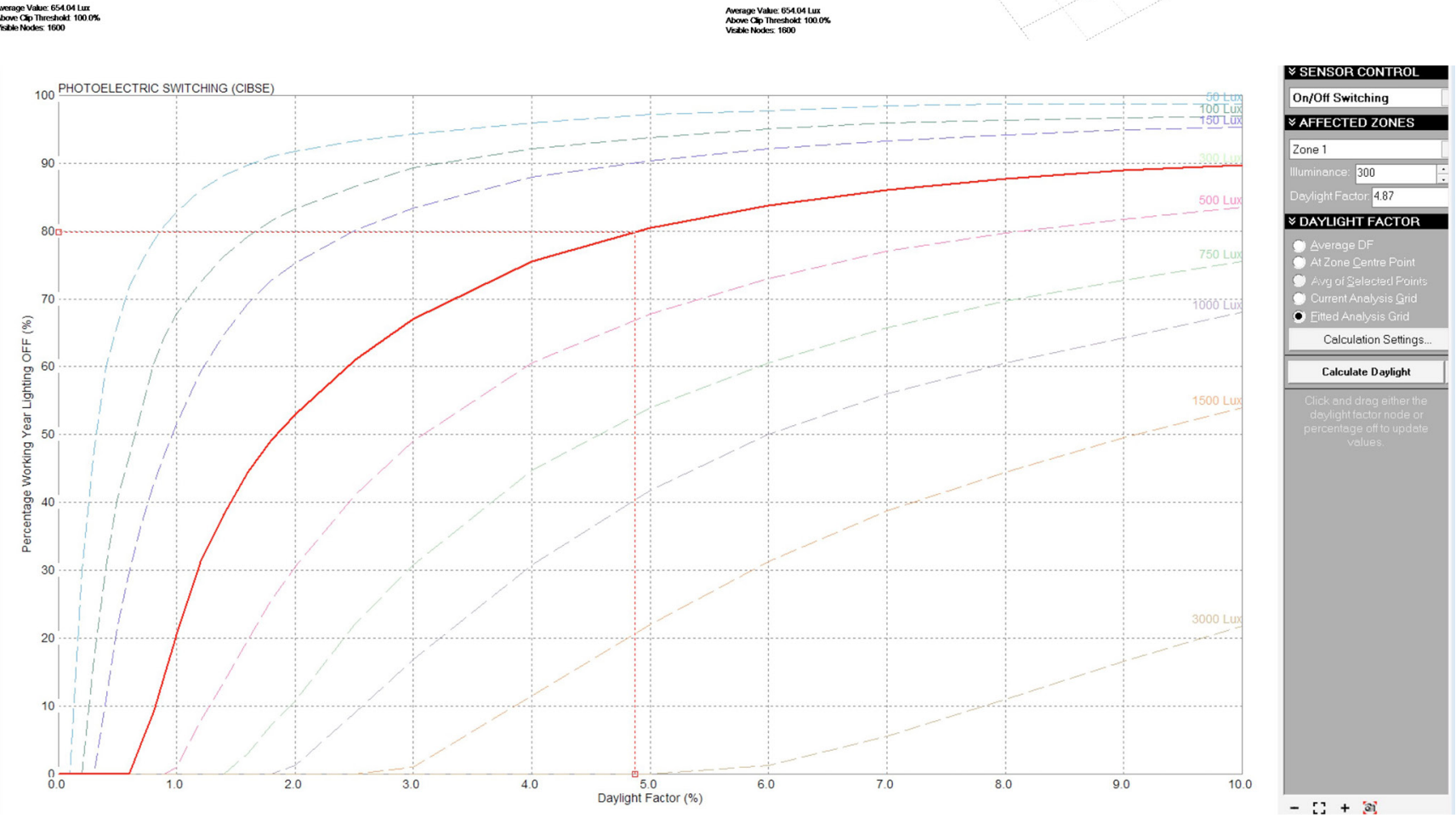
etkinliğinin arttırılması ve sorunların çözümü için kullanılabilir niteliktedir.

\section{Sonuc}

Geliştirilen model, erken tasarım aşamasında günıșığı konusunda destek almak amacıyla tasarımını bu konuda geliștirmek isteyen tasarımcı için kurgulanmıştır.

Model, tasarım sürecinde kullanılan birçok faktör için tasarımı yönlendirici bir karar sistemi oluşturarak toplam kalitenin, tasarımcıya bağlı gelişmesine destek olmaktadır. Günışığı konularında tasarımcının içselleştiremediği ve bu nedenle tasarım sürecine dâhil edemediği birçok faktörün tasarım sürecine dâhil olmasını sağlayarak, tasarımın fiziksel çevreye daha uyumlu, mekânsal konforu yüksek ve sürdürülebilir olmasını sağlamaktadır.

Modelin temelini olușturan ve tasarımcı için aynı zamanda rehber niteliği taşıyan çözümleme așaması, fiziksel çevre sorunlarını belirlenmesini sağlayan bir kaynak niteliğindedir. Tasarımcıya, belirlenen problemlerin çözümünün dışında, mekân için gerekli günışığı faktörlerini açıklamakta ve sistematik olarak değerlendirme firsatı vermektedir.

Tasarım aşamasının en önemli özelliklerinden biri de tasarımcı aktif bir süreç olmasıdır. Tasarımcı planladığı tasarım için en fazla söz söyleme ve tasarımı yönlendirme yetkisine sahip kişidir. Tasarım aşamasına adapte olacak bir destek sisteminin, tasarımcının bu aktif rolü ile uyumlu çalıșması ve tasarımcıya daha fazla imkân vererek tasarımı yönlendirmesine yardımcı olması beklenmektedir. Bu nedenle olușturulan model, tasarımcıyla birçok kere etkileşime girerek ve model içinde aktif rol aldırarak bunu sağlamaktadır.

Model sonucunda, tasarımcı çıkan çözüm ağırlıklarını değerlendirerek tasarımına en uygun çözüm kararını oluşturur. Oluşan çözüm kararı ile birlikte tasarım aşamasına döner ve tasarım süreci devam eder. Çözüm kararlarının doğrulamasının yapılmamasının sebebi, çözüm kararını etkileyen günışığı değerlerinin dışında oldukça çok faktörün olmasıdır. Bu nedenle modelde çıkan karar, bir tavsiye niteliğindedir. Çö-

76 Sayı 29, Mart 2020 züm kararının yorumlanması ve tasarıma yansıtılması tasarımcıya bırakılmıștır.

Model, tasarım aşamasının tüm evrelerinde ya da mevcut bir yapının günışığı sorunlarının belirlenmesinde kullanılabilir niteliktedir. Kurgulanan modelin, tasarım süreci ile uyumlu olduğu, istenilen aşamada sürece tasarımcı tarafindan dâhil edilerek bilgi ürettiği ve üretilmiş bilginin değerlendirilmesini yine tasarımcıya bıraktığı sonucuna varılmıștır.

Model gelişebilir niteliktedir. Günışığ 1 konusundaki gelișmelerin ve analiz tekniklerinin farklılaşması sonucunda daha doğru bilgi üretebileceği kabul edilebilir. Ayrıca modele diğer fiziksel çevre konularının eklenmesi ile daha fazla kriterin tasarıma entegrasyonu sağlanabilir. Modelin ürettiği bilginin ve kararın diğer tasarım kriterleri ile ilişkili değerlendirilmesi (isll konfor, enerji verimliliği, işitsel konfor, yattrum maliyeti, işletme maliyeti, vb) gerekmektedir. Bu yönüyle model gelişime açıktır.

Günümüzde fiziksel çevre konularındaki literatüre bakıldığında, günışığı etkinliğinin tasarımda artmasının faklı tasarım kriterlerini de olumlu etkilediği görülmektedir. Bu yönüyle modelin tasarımcı için herhangi bir tasarımda günıșığı etkinliğini arttırmasının çoğunlukla tasarıma olumlu girdi oluşturacağı düşünülmektedir.

\section{Teşekkür}

Bu çalışma Mimar Sinan Güzel Sanatlar Üniversitesi Yapı Fiziği ve Malzeme Lisansüstü programında Yapı Kabuğu Performans Kriterleri doktora dersi kapsamında hazırlanmıștır. Çalıșmaya katkılarından dolayı Dr. Cüneyt Diri’ye teşekkürlerimizi sunarıє 


\section{Kaynakça}

Acosta, I., Munoz, C., Campano Laborda, M., \& Navarro, J. (2014). Analysis of daylight factors and energy saving allowed by windows under overcast sky conditions. Renewable Energy, 77. Retrieved from https://doi.org/10.1016/j.renene.2014.12.017

Agency, I. E. A. (IEA) S. H. and C., \& Programme, E. C. in B. \& C. S. E. (2000). Daylight in buildings. Lawrence Berkeley National Laboratory.

Antoniou, D., \& Dimopoulos, T. (2018). Southern Orientation and Natural Cross Ventilation: Mind the Gap (s) What Clients, Valuers, Realtors and Architects Believe. RELAND: International Journal of Real Estate \& Land Planning, 1, $426-439$.

Arpacioğlu, Ü. (2010). Günışığı Öncelikli Fiziksel Çevre Tasarım Destek Modeli. Mimar Sinan Güzel Sanatlar Üniversitesi, İstanbul.

Arpacioğlu, Ü. (2012). Mekansal Kalite ve Konfor İçin Önemli Bir Faktör: GÜNIŞIĞI. Mimarlık, 368, 48-53.

Arpacıŏlu, Ü. (2012). Fiziksel Çevre Tasarım Destek Modeli. Tasarım + Kuram Dergisi, 7(11-12), 98-114.(Ü. Olacak)

ASHRAE. (2001). The American Society of Heating, Refrigerating and Air-Conditioning Engineers.

Autodesk. (2011). Ecotect Analysis. Autodesk.

Bellia, L., Cesarano, A., Iuliano, G. F., \& Spada, G. (2008). Daylight glare: a review of discomfort indexes. Visual Quality and Energy Efficiency in Indoor Lighting: Today for Tomorrow.

BRE. (1985). Lighting Controls and Daylight Use. Watford, UK: Building Research Establishment BRE Digest 272 TIM 14947.

BRE. (2011). BREEAM New Construction Non-Domestic Buildings. In BREEAM New Construction NonDomestic Buildings Technical Manual (p. 406).

Byun, Y. H., Ryu, R., \& Kim, Y. S. (2019). Proposal for Light Shelf System that Applies Biomimicry for Lighting Energy Conservation.

Costanzo, V., Evola, G., \& Marletta, L. (2017). A Review of Daylighting Strategies in Schools : State of the Art and Expected Future Trends. Retrieved from https://doi.org/10.3390/buildings7020041

Erel, B. (2004). Gün Işsı̆̆ İle Aydınlatma Alanında Geliştirilen Yeni Teknolojiler Hakkında Bir Araştırma. Fen Bilimleri Enstitüsü.

Garris, L. . (2004). The deliberation of daylighting. Buildings Magazine.

Gornicka, G. B. (2008). Lighting at Work Environmental Study of Direct Effects of Lighting Level and Spectrum on Psychophysiological Variables. Regulation. Retrieved from https://doi. org/10.6100/IR639378

Hamedani, Z., Solgi, E., Skates, H., Hine, T., Fernando, R., Lyons, J., \& Dupre, K. (2019). Visual discomfort and glare assessment in office environments: A review of light-induced physiological and perceptual responses. Building and Environment.

Hülya, O. (2008). Gün Işı̆̆ı ile Aydınlatmanın Temel İlkeleri Ve Gelişmiş Gün Işı̆̆ Yüksek Lisans Tezi, Mimar Sinan Güzel Sanatlar Üniversitesi, İstanbul, Haziran.

IESNA. (2005). Lighting Handbook.

Kayakuș, M. (2018). Eğitim Kurumlarındaki Aydınlatmanın Uluslararası Standartlara Göre İncelenmesi, (November).
Kazanasmaz, Z. T. (2009). Binaların Doğal Aydınlatma Performanslarının Değerlendirilmesi. V. Ulusal Aydinlatma Sempozyuти, Tетти 2009.

Khanie, M. S. S., Wienold, J., \& Andersen, M. (2015). A sensitivity analysis on glare detection parameters. In Proceedings of 14th International Conference of the International Building Performance Simulation Association, Hyderabad, December $7 e 9$.

Kim, K., Lee, H., Jang, H., Park, C., \& Choi, C. (2019). Energy-saving performance of light shelves under the application of user-awareness technology and light-dimming control. Sustainable Cities and Society, 44, 582-596.

Kilıç, E. (1994). Kamaşma ve kamaşmanın belirlenmesinde kullanılan yöntemlerin incelenmesi. Yıldız Teknik Üniversitesi.

Kurtay, C., \& Esen, O. (2018). Ofis yapıları için ıșık rafi tasarımında $30^{\circ}$ ve $45^{\circ}$ enlemlerinde optimum verim sağlanması için bir yöntem. Journal of the Faculty of Engineering \& Architecture of Gazi University, 2018.

Kutlu, R. (2019). BİR Tasarim Öğesi Olarak Günișiği. The Turkish Online Journal of Design Art and Communication, 9(2), 226-233.

Mangkuto, R. A., Rohmah, M., \& Asri, A. D. (2016). Design optimisation for window size, orientation, and wall reflectance with regard to various daylight metrics and lighting energy demand: A case study of buildings in the tropics. Applied Energy, 164, 211-219. Retrieved from https://doi. org/10.1016/j.apenergy.2015.11.046

MEB. (n.d.-a). Milli Eğitim Bakanlığı'nın Tip Tip Okul Projeleri 2016. http://iedb.meb.gov.tr/www/ bakanligimiza-ait-yeni-projeler/icerik/315

MEB. (n.d.-b). Milli Eğitim Bakanlığına Ait Yeni Projeler 2016. http://iedb.meb.gov.tr/katalog/files/mobile/ index.html\#64

Neufert, E. (2002). Architects' Data. ((Oxford Brookes University Baiche, B.; Walliman, N.,Ed.) Blackwell Science.

Olbina, S., \& Beliveau, Y. (2010). Decision-Making Framework for Selection and Design of Shading Devices Based on Daylighting. Journal of Green Building, 2(3), 88-105. Retrieved from https://doi. org/10.3992/jgb.2.3.88

Pierson, C., Wienold, J., \& Bodart, M. (2017). Discomfort glare perception in daylighting: Influencing factors. Energy Procedia, 122, 331-336. Retrieved from https://doi.org/10.1016/j.egypro.2017.07.332

Pierson, C., Wienold, J., \& Bodart, M. (2018). Daylight discomfort glare evaluation with Evalglare: influence of parameters and methods on the accuracy of discomfort glare prediction. Buildings, 8(8), 94

Postalci, I. E., \& Atay, G. F. (2019). Rethinking on cultural sustainability in architecture: Projects of Behruz Cinici. Sustainability (Switzerland), 11(4), 1-17. https://doi.org/10.3390/su11041069

S. Hayter, Torcellini P.A., J. R. (1999). Optimizing building and HVAC systems. ASHRAE Journal.

Şahin, T. (2012). Yapı İçi Aydınlık Düzeyinin Yapı Biyolojisi Açısından Irdelenmesi. T.C. YILDIZ TEKNIK ÜNIVERSITESİ.

Senkal Sezer, F. (2005). Farklı Cam Türlerinin Performan Kriterlerinin İncelenmesi. Uluda $\breve{g}$ Üniversitesi Mühendislik-Mimarlık Fakültesi Dergisi, 10(1), $15-21$.

Suk, J., \& Schiler, M. (2012). Investigation of Evalglare 
software, daylight glare probability and high dynamic range imaging for daylight glare analysis. Lighting Research \& Technology, 45(4), 450-463. Retrieved from https://doi. org $/ 10.1177 / 1477153512458671$

Tașoluk, D. (2014). Mimari tasarıma bir girdi olarak doğal aydınlatma, Konya'daki ofis binalarının doğal aydınlatma bakımından incelenmesi. Selçuk Üniversitesi Fen Bilimleri Enstitüsü.

Türk Standartları Enstitüsü. (2013). Turkish Standard TS EN 12464-1. https://intweb.tse.org.tr/

Tzempelikos, A, \& Athienitis, A. K. (2015). The effect of shading design and control on building cooling demand. Passive and Low Energy Cooling for the Built Environment, (May), 953-958.

Tzempelikos, Athanasios. (2005). A methodology for integrated daylighting and thermal analysis of buildings. Cornell Hotel and Restaurant Administration Quarterly. https://doi. org/10.1177/001088048102200214

Tzempelikos, Athanassios, \& Athienitis, A. K. (2007). The impact of shading design and control on building cooling and lighting demand. Solar Energy, 81(3), 369-382.

Uzun, T. (2019). Bauhaus Ekolü Ve Kuramsal Arka Planı. In Mimarlik, Planlama ve Tasarım Alanında Yeni Ufuklar (1. Bask1, pp. 411-448). Ankara: Gece Akademi yayınları.

Vaisi, S., \& Kharvari, F. (2019). Evaluation of Daylight regulations in buildings using daylight factor analysis method by radiance. Energy for Sustainable Development, 49, 100-108.

Yener, A. K. (2007). Binalarda Günıșığından Yararlanma Yöntemleri: Çağdaș Teknikler. 8. Ulusal Tesisat Mühendisliği Kongresi. Temmuz 2007.

Yilmaz, F. Ş. (2016). Energy efficient lighting system retrofit for retail environments. ITU A/Z Journal, 13(1), 209-224. Retrieved from https://doi. org/10.5505/ituifa.2016.30502

YTÜ Mimarlık Fakültesi (2019). Aydınlatma Laboratuvarı Çalışma Notları (Deney Föyü). 